\title{
Diazotrophy as the main driver of the oligotrophy gradient in the western tropical South Pacific Ocean: results from a one-dimensional biogeochemical-physical coupled model
}

\author{
Audrey Gimenez, Melika Baklouti, Thibaut Wagener, and Thierry Moutin \\ Aix Marseille Univ., CNRS, Université de Toulon, IRD, OSU Pythéas, Mediterranean Institute of Oceanography (MIO), \\ UM 110, 13288, Marseille, France
}

Correspondence: Audrey Gimenez (audrey.gimenez@mio.osupytheas.fr) and

Melika Baklouti (melika.baklouti@mio.osupytheas.fr)

Received: 8 April 2018 - Discussion started: 12 April 2018

Revised: 20 August 2018 - Accepted: 16 September 2018 - Published: 7 November 2018

\begin{abstract}
The Oligotrophy to UlTra-oligotrophy PACific Experiment (OUTPACE) cruise took place in the western tropical South Pacific (WTSP) during the austral summer (March-April 2015). The aim of the OUTPACE project was to investigate a longitudinal gradient of biological and biogeochemical features in the WTSP, and especially the role of $\mathrm{N}_{2}$ fixation in the $\mathrm{C}, \mathrm{N}$, and $\mathrm{P}$ cycles. Two contrasted regions were considered in this study: the Western Melanesian Archipelago (WMA), characterized by high $\mathrm{N}_{2}$ fixation rates, significant surface production and low dissolved inorganic phosphorus (DIP) concentrations, and the South Pacific Gyre (WGY), characterized by very low $\mathrm{N}_{2}$ fixation rates, surface production and high DIP concentrations. Since physical forcings and mixed layer dynamics in both regions were similar, it was considered that the gradient of oligotrophy observed in situ between the WMA and WGY was not explained by differences in physical processes, but rather by differences in biogeochemical processes. A one-dimensional physical-biogeochemical coupled model was used to investigate the role of $\mathrm{N}_{2}$ fixation in the WTSP by running two identical simulations, only differing by the presence ( sim $^{\mathrm{WMA}}$ ) or absence ( $\operatorname{sim}^{\mathrm{WGY}}$ ) of diazotrophs. We showed that the nitracline and the phosphacline had to be, respectively, deeper and shallower than the mixed layer depth (MLD) to bring Ndepleted and P-repleted waters to the surface during winter mixing, thereby creating favorable conditions for the development of diazotrophs. We also concluded that a preferential regeneration of the detrital phosphorus $(\mathrm{P})$ matter was necessary to obtain this gap between the nitracline and phosphacline depths, as the nutricline depths significantly depend
\end{abstract}

on the regeneration of organic matter in the water column. Moreover, the model enabled us to highlight the presence of seasonal variations in primary production and $\mathrm{P}$ availability in the upper surface waters in simWMA, where diazotrophs provided a new source of nitrogen $(\mathrm{N})$ to the ecosystem, whereas no seasonal variations were obtained in simWGY, in the absence of diazotrophs. These main results emphasized the fact that surface production dynamics in the WTSP is based on a complex and sensitive system which depends on the one hand on physical processes (vertical mixing, sinking of detrital particles), and on the other hand on biogeochemical processes ( $\mathrm{N}_{2}$ fixation, remineralization).

\section{Introduction}

The efficiency of the oceanic carbon (C) sequestration depends upon a complex balance between the organic matter production in the euphotic zone and its remineralization in both the epipelagic and mesopelagic zones. The growth of autotroph organisms, and therefore the assimilation of $\mathrm{CO}_{2}$, is strongly linked to the nutrients' availability in the ocean surface layer (de Baar, 1994). Although nitrate $\left(\mathrm{NO}_{3}^{-}\right)$and ammonium $\left(\mathrm{NH}_{4}^{+}\right)$are the two main $\mathrm{N}$ sources taken up by autotrophs, their concentrations remain very low in the oligotrophic ocean and often growth-limiting in most of the open ocean euphotic layer (Falkowski et al., 1998). In contrast to $\mathrm{NO}_{3}^{-}$and $\mathrm{NH}_{4}^{+}$, the dissolved dinitrogen $\left(\mathrm{N}_{2}\right)$ gas in seawater is very abundant in the euphotic zone and could be consid- 
ered an inexhaustible $\mathrm{N}$ source for the marine ecosystems. Some prokaryotic organisms (Bacteria, Cyanobacteria, Archaea), commonly called diazotrophs or " $\mathrm{N}_{2}$ fixers", are able to use this gaseous $\mathrm{N}$ source by converting it into a usable form (i.e., $\mathrm{NH}_{3}$ ) due to the nitrogenase enzyme system (Zehr and McReynolds, 1989; Zehr and Turner, 2001). In addition to providing a new source of nitrogen for themselves, diazotrophs release a fraction of the fixed $\mathrm{N}$ in the dissolved pool in the form of $\mathrm{NH}_{4}^{+}$and dissolved organic $\mathrm{N}$ (DON) in the surface waters (Bronk and Ward, 2000; Mulholland et al., 2004, 2006; Benavides et al., 2013; Berthelot et al., 2015) and thus contribute to sustaining life and potentially $\mathrm{C}$ export. This new $\mathrm{N}$ input would seem to bring a positive advantage to the $\mathrm{C}$ biological pump since it would reduce the $\mathrm{N}$ limitation for the phytoplankton and thus enhance primary production in oligotrophic regions. However, even if diazotrophs are not limited by atmospheric $\mathrm{N}_{2}$, their growth is controlled by other factors, including the availability of dissolved iron (DFe) and dissolved inorganic phosphate (DIP) (Moutin et al., 2005; Karl and Letelier, 2008). Moreover, chemostat experiments have highlighted that $\mathrm{N}_{2}$ fixation activity was highly dependent on the circadian clock and that the success of non-diazotrophs and diazotrophs depends on the interplay between light intensity and DIN concentration, and the competition for those resources (Rabouille et al., 2006; Agawin et al., 2007). In a synthesis paper, Gruber (2004) reminds us that over the last decades, the work on $\mathrm{N}_{2}$ fixation and the diversity of diazotroph organisms has shown a significant contribution of $\mathrm{N}_{2}$ fixation to primary production in the global ocean (Falkowski, 1997; Gruber and Sarmiento, 1997; Capone et al., 1997; Karl et al., 2002), thereby calling into question the classical paradigm of the $\mathrm{N}$ limitation in the open ocean (Zehr and Kudela, 2011).

Furthermore, in the current context of climate change, Polovina et al. (2008) showed that global warming would intensify the stratification of surface waters in tropical and subtropical oceans, further reducing nutrient concentrations in the euphotic layer. It is therefore crucial to study in detail the coupling of the biogenic element cycles in the oligotrophic regions to better understand all the interactions between the processes involved in the surface production and therefore in the $\mathrm{C}$ biological pump. The Oligotrophy to UlTraoligotrophy PACific Experiment (OUTPACE) cruise has as its main objective to study how production, mineralization and export of organic matter, and associated biogenic elements of $\mathrm{C}, \mathrm{N}$, and $\mathrm{P}$ biogeochemical cycles, depend on the $\mathrm{N}_{2}$ fixation process. Along the transect covered during the OUTPACE cruise, a longitudinal gradient of DIP availability was observed from low concentrations in the Melanesian Archipelago (MA) to higher concentrations in the South Pacific Gyre (SPG) (Moutin et al., 2018), closely related to an opposite gradient of primary production (Van Wambeke et al., 2018) and $\mathrm{N}_{2}$ fixation rates (Bonnet et al., 2017; Caffin et al., 2018). In the framework of the OUTPACE study, it appeared crucial to investigate in detail the role of $\mathrm{N}_{2}$ fixation in the surface production, using a modeling approach combining a 3-D modeling study at regional scale (Dutheil et al., 2018) and a process-focused study using a one-dimensional model (this work), with the aim of explaining the contrasted ecosystems and biogeochemical cycles observed in the western tropical South Pacific (WTSP). Since experimental studies highlighted the significant contribution of $\mathrm{N}_{2}$ fixation as a source of $\mathrm{N}$ for planktonic ecosystems in the surface layer (Martínez et al., 1983; Karl et al., 1997; Capone et al., 2005), the process of diazotrophy associated (or not) with explicitly represented diazotroph organisms has been implemented in numerous biogeochemical models in the last decades. As a result, more and more modeling studies have been investigating the role of diazotrophy at global scale (Moore et al., 2002, 2004; Monteiro et al., 2011), at regional scale (Coles and Hood, 2007; Zamora et al., 2010), at local scale (Fennel et al., 2002; Gimenez et al., 2016) or more specifically at population scale (Rabouille et al., 2006; Grimaud et al., 2013). While three-dimensional (3-D) models provide a general view of the studied ecosystems, computational costs often restrict the spatial and temporal resolutions and/or the complexity of the biogeochemical model. By contrast, onedimensional models only provide a local view, but enable an accurate study of the biogeochemical processes deconvoluted from horizontal marine dynamics, at physiological (days) and ecological (months to years) timescales. In this work, we used a one-dimensional physical-biogeochemical coupled model to simulate the dynamics of the complex ecosystems observed during the OUTPACE cruise, and built two simulations to represent each of two highly contrasted regions sampled during the OUTPACE cruise, namely the Western Melanesian Archipelago (WMA) and the Western South Pacific Gyre (WGY) (see Fig. 2). One of these simulations was run with diazotrophy as a proxy of the WMA region, and the second without diazotrophy as a proxy of the WGY region, to implicitly take into account the role of DFe allowing $\mathrm{N}_{2}$ fixation in the MA but preventing it in the gyre (Moutin et al., 2008; Bonnet et al., 2017). The purpose of this study is to investigate the direct and/or indirect role of $\mathrm{N}_{2}$ fixation in surface planktonic production and biogeochemical $\mathrm{C}, \mathrm{N}$, and $\mathrm{P}$ cycles, with the aim of determining whether the main biogeochemical differences observed in the MA and in the SPG areas can be explained or not by diazotrophy.

\section{Methods}

\subsection{Strategy of the OUTPACE cruise and of the modeling study}

The OUTPACE cruise was carried out between 18 February and 3 April 2015 from Noumea (New Caledonia) to Papeete (French Polynesia) in the WTSP (Fig. 2). Two types of stations were sampled: 15 short-duration (SD) stations dedicated to the study of the longitudinal variations of biodi- 
versity and biogeochemistry, and 3 long-duration (LD) stations where Lagrangian experiments and several additional measurements (such as measurements on the settling of organic matter using sediment traps) were carried out during 6 days. The details of all the operations conducted at the different stations are summarized in Moutin et al. (2017), with a focus on the Lagrangian strategy followed at the LD stations in de Verneil et al. (2018). Along the eastward transect from the MA to the SPG, three areas were considered regarding their different biogeochemical characteristics: the western MA (WMA), the eastern MA (EMA) and the western gyre (WGY) waters (Moutin et al., 2018). In this study, we focused on the comparison of the two most contrasted areas, namely the WMA and the WGY (Fig. 2). While both the WMA and WGY present extremely low nitrate concentrations in the photic layer, the WMA presents higher surface production, higher $\mathrm{N}_{2}$ fixation rates and lower phosphate concentrations than the WGY.

As already mentioned, in order to investigate the role of $\mathrm{N}_{2}$ fixation in the WTSP, we ran two identical simulations, one including the process of diazotrophy, hereafter named "simWMA", and the second without this process, hereafter named "simWGY". Except for the process of diazotrophy, the two simulations were strictly identical regarding the atmospheric forcings, the initial conditions, the model formulation and the parameter values. The assumption made by using a unique set of atmospheric forcings for two regions significantly far away is first based on the in situ climatological data reported in Moutin et al. (2018). These authors showed that the vertical dynamics of the water column, and especially the depths of the mixed layer, were similar throughout the year in all of the WTSP (see Fig. S1 in the Supplement). In addition, the atmospheric forcings calculated by the WRF atmospheric model at the WMA and WGY were also very similar (see Fig. S2 in the Supplement). Furthermore, we also compared two simulations run with the respective atmospheric forcings calculated at the WMA and WGY and did not observe any significant difference, neither in the water column dynamics nor in the biogeochemical cycles.

The methods used to measure dissolved inorganic nitrogen (DIN), DIP, $\mathrm{N}_{2}$ fixation $\left(\mathrm{N}_{2}\right.$ fix), chlorophyll $a(\mathrm{Chl} a)$, primary production (PP) and particulate organic carbon (POC), as well as the corresponding data, are fully described in the companion paper by Moutin et al. (2018). For ease of reading, the following abbreviations will be used: for a given variable " $X$ ", abbreviations $X^{\operatorname{simWMA}}$ and $X^{\operatorname{simWGY}}$ will be used for the model outputs, respectively, with and without diazotrophy, and $X^{\text {obsWMA }}$ and $X^{\text {obsWGY }}$ for the experimental data measured at the WMA and WGY, respectively.

Model outputs were compared to the observations gathered during the OUTPACE cruise at the WMA and WGY. For each profile presented in the Results section, we plotted the discrete values of the data collected at the WMA and WGY (circles), and the average over the respective sampling periods of the WMA and WGY for the model results (from
21 February 2015 to 2 March 2015 for simWMA, and from 21 to 31 March 2015 for simWGY). Both simulations were run over 10 years. Since a cyclic steady state was reached in the near-surface layer after 3 years, the vertical profiles of the third year of simulation (solid line) are presented for both simWMA and simWGY. Moreover, since the outputs of simWMA provided interesting information regarding the role of diazotrophs in fueling the system with new $\mathrm{N}$ inputs, the 10 vertical profiles of the 10 -year run are all presented in the Results section.

\subsection{The biogeochemical model}

The biogeochemical model implemented in this work is embedded in the Eco3M modular numerical tool (Baklouti et al., 2006). It was based on the Eco3M-MED model (Alekseenko et al., 2014) to which two diazotrophs were added for studying $\mathrm{N}_{2}$ fixation fate in the framework of a mesocosm experiment in the Noumea lagoon (Gimenez et al., 2016). For the present study, and in order to improve the model, some features of the original model presented in Gimenez et al. (2016) were modified and some new features were introduced (see Sect. 2.2.2).

\subsubsection{General backgrounds}

The model includes eight planktonic functional types (PFTs): four autotrophs (a large and a small classic phytoplankton and a large and a small nitrogen fixer), three grazers (zooplankton) and one decomposer (heterotrophic bacteria). Each of them is represented in terms of several concentrations $(C$, $\mathrm{N}, \mathrm{P}$ and chlorophyll for phytoplankton) and an abundance (cells or individuals per liter) (Mauriac et al., 2011). Each PFT is represented by emblematic organisms indicated in brackets, and for ease of reading, living compartments are abbreviated as follows: TRI for the large diazotrophs (Trichodesmium sp.), UCYN for the small diazotrophs (unicellular nitrogen fixers), PHYS for the small autotrophs (picophytoplankton and nanophytoplankton), PHYL for the large autotrophs (diatoms), HNF for nanozooplankton (heteronanoflagellates), CIL for microzooplankton (cilliates) and COP for mesozooplankton (copepods). For all the nondiazotrophic features and in agreement with the literature (e.g., Luo et al., 2012), it has been considered that a Trichodesmium trichome was equivalent to 100 PHYL cells and that a UCYN cell was equivalent to a PHYS cell. However, the conversion factor of 100 between TRI and PHYL was only applied for extensive parameters, i.e., those depending on biomass. Intensive parameters were set equal to those of PHYL, except for the specific growth rate, which was instead averaged from the literature since it has been experimentally demonstrated that it was lower than that of PHYL (Mulholland and Bernhardt, 2005; Hutchins et al., 2007). Parameter values, whether new or differing from those of Alekseenko et al. (2014), are given in Supplement Table S1. 


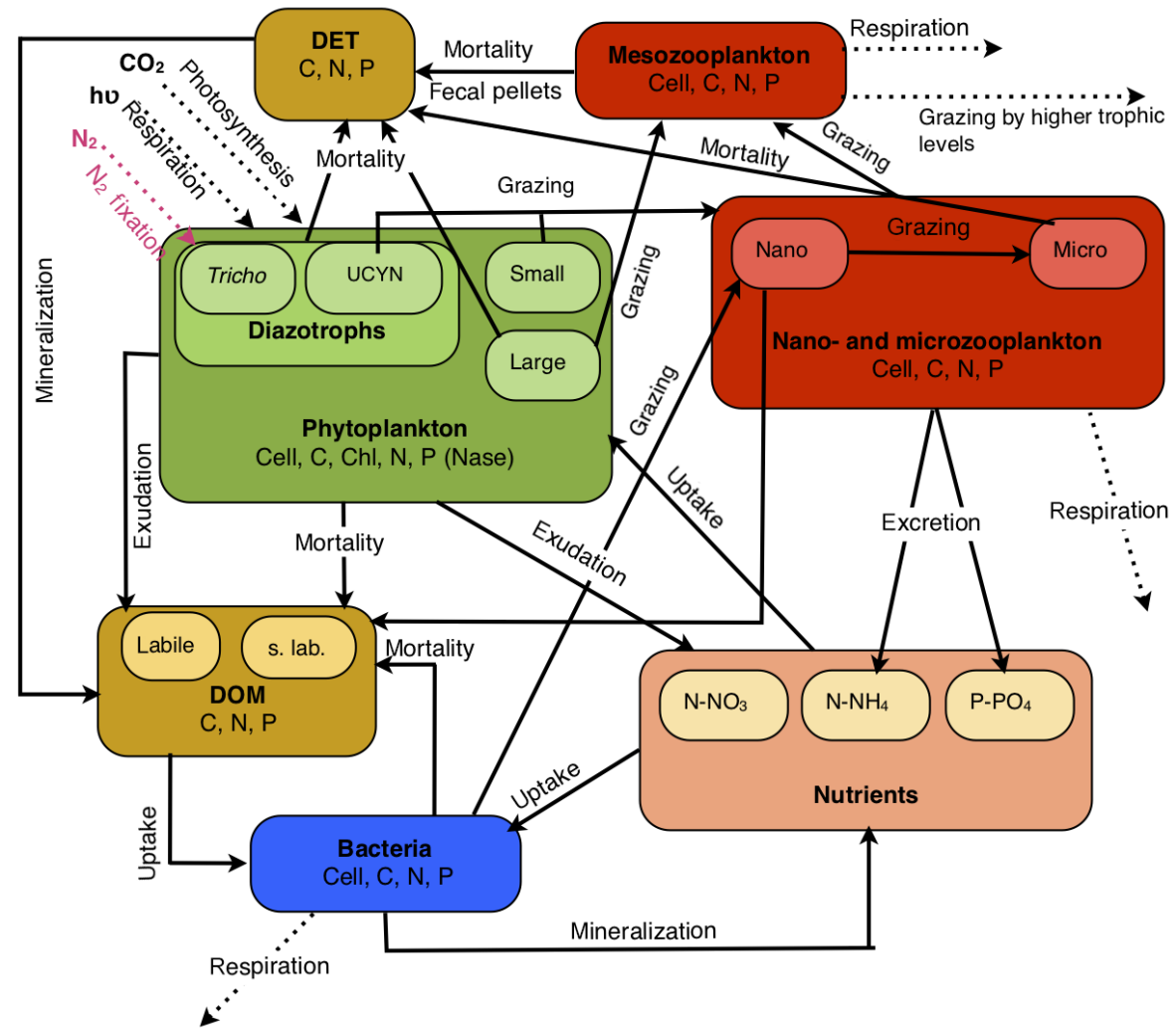

Figure 1. Conceptual diagram of the biogeochemical model (Eco3M-Med enhanced with diazotrophs) from the 1 DV coupled physicalbiogeochemical used for the OUTPACE project.

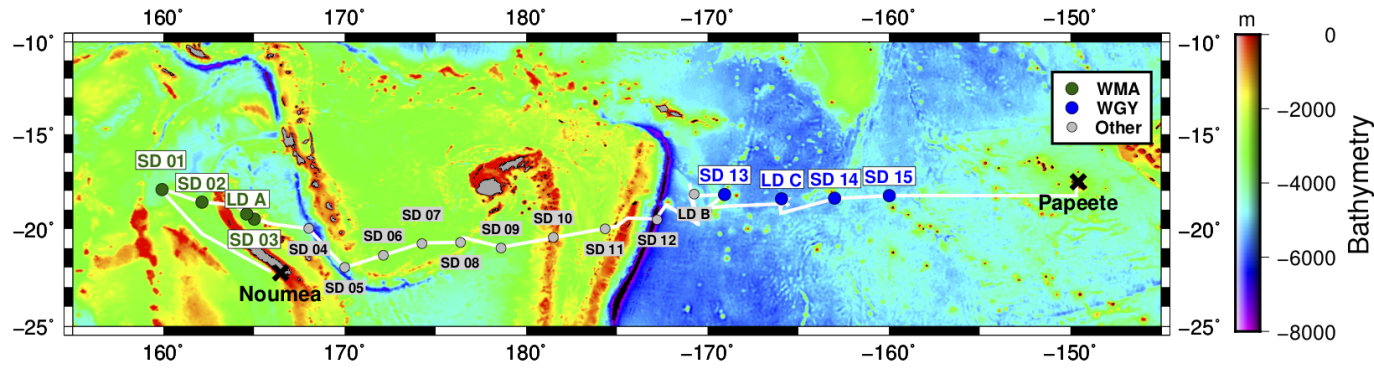

Figure 2. Transect of the OUTPACE cruise with the location of the SD and LD stations superimposed on a bathymetry map (GEBCO_2014 grid). The two main regions studied in this work are shown in green for the WMA and in blue for the WGY.

In the model, $\mathrm{N}_{2}$ fixation rates depend on the nitrogenase enzyme activity (Nase) (Rabouille et al., 2006; Gimenez et al., 2016); nitrogen fixation is the result of a balance between the increase and decrease in the enzyme activity, which is controlled by the intracellular content in $\mathrm{C}$ and $\mathrm{N}$, and by the $\mathrm{NO}_{3}^{-}$concentration. The more the cell is deprived of nitrogen, the more the nitrogenase activity is enhanced, but under the control of the intracellular $\mathrm{C}$ content which plays the role of "energy regulator", being tightly linked to the daily light cycle (Rabouille et al., 2006). Further details regarding the implementation of diazotrophy in the model are available in Gimenez et al. (2016). All the compartments and fluxes implemented in the model are summarized in Fig. 1.

\subsubsection{New features of the model}

Since the Gimenez et al. (2016) modeling study was focusing on a mesocosm experiment, the assessment of the model skills was incomplete. With the new set of data provided by the OUTPACE cruise, some features of the original model were improved and some new features were introduced to correct the model major flaws or to add some realism to the model. To improve the representation of the nutricline depths 
which depend on the sinking of the detrital organic matter and its mineralization in the water column, we included two size classes of detrital matter associated with two different sinking rates, while the previous version (Gimenez et al., 2016) only included a single compartment of detrital material (see Table S1 in the Supplement). The large detrital particles (DETL) are fueled by the death of COP, their fecal pellets and the quadratic mortality of PHYL. The small detrital particles (DETS) are fueled by the hydrolysis of DETL and by the linear mortality of PHYL, TRI and CIL, whereas the mortality of PHYS, UCYN, HNF and BAC fills the compartment of dissolved organic matter (DOM). The sinking rates for DETS and DETL are 1 and $25.0 \mathrm{~m} \mathrm{~d}^{-1}$, respectively.

While several studies have shown that the intracellular $\mathrm{C}: \mathrm{N}: \mathrm{P}$ ratios in heterotrophic bacteria tend to be below Redfield values as they were enriched in $\mathrm{N}$ and $\mathrm{P}$ (Bratbak, 1985; Goldman and Dennett, 2000; Vrede et al., 2002), more recent studies suggest that these ratios could be higher than $50: 10: 1$ and highly variable in response to physical, chemical and physiological conditions (Cotner et al., 2010; Martiny et al., 2013; Zimmerman et al., 2014). This led us to replace the $50: 10: 1$ ratios used so far in the model for bacteria and HNF with the Redfield 106: $16: 1$ ratio as with the other PFTs represented in the model. We remind the reader however that the PFT's stoichiometry is flexible in the model and that the Redfield ratios are only used to link together the limits of the ranges of $\mathrm{C}, \mathrm{N}$ and $\mathrm{P}$ intracellular quotas (i.e., $Q_{\mathrm{C}}^{\min }=106 Q_{\mathrm{P}}^{\min }, Q_{\mathrm{C}}^{\max }=106 Q_{\mathrm{P}}^{\max }$; see Table $\mathrm{S} 1$ in the Supplement), thereby allowing a large variety of possible $\mathrm{C}: \mathrm{N}: \mathrm{P}$ ratios in PFTs.

Moreover, in this oligotrophic to ultra-oligotrophic region, the regeneration of the organic matter is crucial to maintaining the ecosystem balance, and certain modifications have been made in this regard: (1) to indirectly take into account the enhanced consumption of organic $\mathrm{P}$ through the activity of extracellular alkaline phosphatase produced by bacteria in oligotrophic areas (Perry, 1972, 1976; Vidal et al., 2003), all the half-saturation constants (Ks) for the DOP uptake were divided by 1 order of magnitude, (2) the hydrolysis rate of the particulate organic $\mathrm{P}$ was modified (from 0.4 to $2.0 \mathrm{~d}^{-1}$ ) to increase the regeneration of $\mathrm{P}$ compared to $\mathrm{C}$ and $\mathrm{N}$ in this P-depleted area (detailed in Sect. 4.2.2).

\subsection{One-dimensional physical model and forcings}

The biogeochemical model has been coupled with the onedimensional physical model described in Gaspar (1988). This model solves the conservation equations for heat, salinity, momentum and kinetic energy. The grid cell is $5 \mathrm{~m}$ high from the surface to $200 \mathrm{~m}$, and $40 \mathrm{~m}$ high from 200 to $2000 \mathrm{~m}$. It uses a simple eddy kinetic energy parametrization with a turbulence closure scheme, resolved by the turbulent kinetic energy (TKE) equation (Gaspar et al., 1990).

The atmospheric forcings (i.e., the sensible and latent heat fluxes, the short- and long-wave radiation and the wind stress) for the physical model were provided by the Weather Research Forecast (WRF) model (Shamarock et al., 2008), with a spatial resolution of $15 \mathrm{~km}$ and a time step of $6 \mathrm{~h}$. Boundary conditions for the WRF model are provided by the American Global Forecast System (GFS) model (National Center for Environmental Prediction/National Center Environmental Prediction - NCAR/NCEP) analyses. These analyses correspond to a correction of the forecast using a larger number of observations during the data assimilation cycle. The WRF model is forced every $6 \mathrm{~h}$ by analyses during the processing. Only a single year of atmospheric forcing has been extracted (from September 2014 to August 2015), which was applied on a cyclical basis during the 10-year simulation. This 1 -year period has been arbitrarily chosen so as to cover the period from the winter mixing preceding the OUTPACE cruise to the next winter. The comparison between some physical outputs (i.e., surface temperature, surface density, mixed layer depth) and climatological in situ observations allowed one to ensure that the onedimensional physical model was relevant to addressing our scientific question (see Fig. S3 in the Supplement).

\subsection{Initialization for the one-dimensional coupled physical-biogeochemical model}

The initial profiles of temperature $(T)$, salinity $(S)$, DIN and DIP were constructed by interpolating mean field data from the WOA13 climatology database (Locarnini et al., 2013; Zweng et al., 2013) at the exact location of the WMA $\left(19^{\circ} 13.00 \mathrm{~S}, 164^{\circ} 29.40 \mathrm{~W}\right)$. Initial dissolved organic matter concentrations, BAC and autotroph abundances were obtained from the vertical profiles measured in the WMA: due to the homogeneity of the surface layer caused by winter mixing, the $0-70 \mathrm{~m}$ mean value was applied on the 0 $70 \mathrm{~m}$ layer of the initial vertical profiles. Below $70 \mathrm{~m}$, initial concentrations were the same as data. Since the model includes variable stoichiometry for organisms, initial intracellular contents of non-diazotroph organisms were set to $50 \%, 25 \%$ and $75 \%$ of their respective intracellular quota ranges in $\mathrm{C}, \mathrm{N}$ and $\mathrm{P}$. While there was no difference in initial $\mathrm{C}$ and $\mathrm{P}$ intracellular contents between diazotroph and non-diazotroph organisms, initial $\mathrm{N}$ intracellular contents of diazotrophs were set up to $50 \%$ to take into account their metabolic advantage of fixing $\mathrm{N}_{2}$. Initial concentrations of detrital compartments are nil. Initial zooplankton abundances were obtained from the BAC abundances using a BAC $: \mathrm{HNF}: \mathrm{CIL}=1000: 100: 1$ ratio. In simWGY where diazotrophs are removed, initial abundances and biomasses of TRI and UCYN were, respectively, transferred in PHYL and PHYS compartments, in order to strictly preserve the same initial biomasses and abundances in the two simulations. 


\section{Results}

\subsection{Vertical dynamics of the main biogeochemical stocks and flux}

\subsubsection{Nutrients availability and $\mathbf{N}_{2}$ fixation}

DIN and DIP concentrations are presented in Fig. 3a and b. Strictly, DIP is the sum of orthophosphates (i.e., $\left.\mathrm{DIP}=\left[\mathrm{H}_{3} \mathrm{PO}_{4}\right]+\left[\mathrm{H}_{2} \mathrm{PO}_{4}^{-}\right]+\left[\mathrm{HPO}_{4}^{2-}\right]+\left[\mathrm{PO}_{4}^{3-}\right]\right)$, and DIN is the sum of nitrate, nitrite and ammonium $\left(\mathrm{DIN}=\left[\mathrm{NO}_{3}^{-}\right]+\right.$ $\left.\left[\mathrm{NO}_{2}^{-}\right]+\left[\mathrm{NH}_{4}^{+}\right]\right)$. However, since $\left[\mathrm{NO}_{2}^{-}\right]$and $\left[\mathrm{NH}_{4}^{+}\right]$were negligible compared to $\left[\mathrm{NO}_{3}^{-}\right]$, DIN was assimilated into $\left[\mathrm{NO}_{3}^{-}\right]$. From the surface to $70 \mathrm{~m}$ depth, DIN ${ }^{\text {obsWMA }}$ and DIN $^{\text {obs WGY }}$ are below the quantification limit (i.e., $0.05 \mu \mathrm{M}$ ). DIN $^{\text {simWMA }}$ and DIN ${ }^{\text {simWGY }}$ do not show any significant difference in the surface layer and range from 0.02 to $0.04 \mu \mathrm{M}$ and from 0.03 to $0.04 \mu \mathrm{M}$ for DIN ${ }^{\text {simWMA }}$ and DIN ${ }^{\text {simWGY, }}$ respectively. Even if the concentrations of DIP are low in the surface layer (below $0.2 \mu \mathrm{M}$ ), some differences can be seen between the WMA and WGY for both model outputs and data. Figure $3 \mathrm{~b}$ shows a concentration around $0.2 \mu \mathrm{M}$ for DIP ${ }^{\text {obswGY }}$ from the surface to $120 \mathrm{~m}$, whereas DIP ${ }^{\text {obsWMA }}$ is very low, with values below the quantification limit $(0.02 \mu \mathrm{M})$ at the subsurface, with a steady increase up to $0.5 \mu \mathrm{M}$ at $300 \mathrm{~m}$ depth. Regarding the model outputs, DIP simWMA is close to zero from the surface to $60 \mathrm{~m}$, and reaches a value of $0.70 \mu \mathrm{M}$ at $300 \mathrm{~m}$ depth. DIPsimWGY is significantly higher than DIP simWMA in the upper layer, with a homogeneous concentration of $0.16 \mu \mathrm{M}$ from the surface to $175 \mathrm{~m}$ depth, and then increases slightly up to $0.7 \mu \mathrm{M}$ at $300 \mathrm{~m}$.

The vertical profiles of DIN ${ }^{\text {simWMA }}$ and DIP ${ }^{\text {simWMA }}$ show a deeper nitracline (around $75 \mathrm{~m}$ depth) than phosphacline (around $60 \mathrm{~m}$ depth), as observed with data. Note that to reproduce this discrepancy within the model, it has been necessary to introduce a preferential regeneration of the detrital matter in $\mathrm{P}$ compared to $\mathrm{C}$ and $\mathrm{N}$ in the biogeochemical model, a point thereafter detailed in Sect. 4.2.2. Regarding the WGY region, the observed and simulated nitracline and phosphacline are deeper than in the WMA region. The simulated nutriclines are however deeper than those measured (around 140 and $125 \mathrm{~m}$ for the simWGY nitracline and phosphacline depths, respectively). While the simulated and measured nitracline depths are both around $75 \mathrm{~m}$ at the WMA, DIN ${ }^{\text {simWMA }}$ is higher than DIN ${ }^{\text {obsWMA }}$ below the nitracline. There is indeed a regular accumulation of DIN ${ }^{\text {simWMA }}$ below the photic zone during the 10-year simulation (Fig. 3a), reaching at the end a high concentration of $17 \mu \mathrm{M}$ that is not observed in DIN ${ }^{\text {obswMA }}$. Even if we may also note a slight variation in the phosphacline over time in simWMA, it is much less significant than the above-mentioned change in the simulated nitracline.

The $\mathrm{N}_{2}$ fixation rates $\left(\mathrm{N}_{2}\right.$ fix) measured at the WMA and WGY and the vertical profiles of $\mathrm{N}_{2}$ fix ${ }^{\text {simWMA }}$ are pre- sented in Fig. 3c. At the surface, $\mathrm{N}_{2}$ fix ${ }^{\text {obsWMA }}$ ranges from 9.0 to $30.0 \mathrm{nmolN} \mathrm{L}^{-1} \mathrm{~d}^{-1}$, with a maximum rate of 35.0 nmolN L $^{-1} \mathrm{~d}^{-1}$ near $10 \mathrm{~m}$ depth. $\mathrm{N}_{2}$ fix ${ }^{\text {obsWMA }}$ then decreases gradually with depth to $9.0 \mathrm{nmolN} \mathrm{L}^{-1} \mathrm{~d}^{-1}$ at $40 \mathrm{~m}$ before reaching low values below $40 \mathrm{~m}$, with values less than $1.5 \mathrm{nmolN} \mathrm{L}^{-1} \mathrm{~d}^{-1}$ and a minimum of $0.1 \mathrm{nmolN} \mathrm{L}^{-1} \mathrm{~d}^{-1}$ at $100 \mathrm{~m}$. Regarding the model results of the simulation with diazotrophy, $\mathrm{N}_{2}$ fix ${ }^{\text {simWMA }}$ rates are consistent with data with a similar trend of higher rates (around $16.0 \mathrm{nmolN} \mathrm{L}^{-1} \mathrm{~d}^{-1}$ ) from the surface to $40 \mathrm{~m}$ depth, and decreasing values from 40 to $70 \mathrm{~m}$ depth (down to $1.0 \mathrm{nmolN} \mathrm{L}^{-1} \mathrm{~d}^{-1}$ at $70 \mathrm{~m}$ ). At the WGY, very low $\mathrm{N}_{2}$ fix ${ }^{\text {obsWGY }}$ was measured compared to $\mathrm{N}_{2}$ fix ${ }^{\text {obswMA }}$, with a maximum rate of $2.0 \mathrm{nmolN} \mathrm{L}^{-1} \mathrm{~d}^{-1}$ observed at the surface. In the simulation without diazotrophy, $\mathrm{N}_{2} \mathrm{fix}^{\text {simWGY }}$ is nil (see Fig. 3c).

\subsubsection{Chlorophyll $a$, primary production and carbon biomass}

Figure 3 shows the vertical profiles of (d) primary production (PP), (e) chlorophyll $a$ concentration (chl $a$ ) and (f) particulate organic carbon (POC) from the surface to $300 \mathrm{~m}$ depth. PP is significantly higher in WMA than in WGY, in both the experimental data and the model results. At the surface, $P P^{\text {obsWMA }}$ ranges from 4.0 to $16.0 \mathrm{mgC} \mathrm{m}^{-3} \mathrm{~d}^{-1}$, while PP ${ }^{\text {obsWGY }}$ never exceeds $1.5 \mathrm{mgC} \mathrm{m}^{-3} \mathrm{~d}^{-1}$. PP ${ }^{\text {simWGY }}$ never exceeds $1.0 \mathrm{mgC} \mathrm{m}^{-3} \mathrm{~d}^{-1}$ and is in good agreement with PPobsWGY in the whole photic layer. PP ${ }^{\text {simWMA }}$ is also in good agreement with PPobsWMA, even if PPsimWMA values are close to the upper limit of the PP ${ }^{\text {obsWMA }}$ range values. As for PP ${ }^{\text {obsWMA }}$, PP ${ }^{\text {simWMA }}$ slightly decreases from the the surface to the bottom of the photic layer, before reaching low rates below $70 \mathrm{~m}$.

The main differences between Chl $a^{\text {obsWMA }}$ and Chl $a^{\text {obsWGY }}$ lie in the depth of the deep chlorophyll maximum (DCM), which is around $75 \mathrm{~m}$ for $\mathrm{Chl} a^{\text {obsWMA }}$, while the Chl $a^{\text {obsWGY }}$ DCM is deeper, at around $140 \mathrm{~m}$. The deepening of the DCM in the WGY compared to the WMA is a result also observed in simWGY and simWMA simulations. This deepening is nevertheless larger in the model with a DCM for $\mathrm{Chl} a^{\text {simWGY }}$ located at $200 \mathrm{~m}$, while the DCM for Chl $a^{\text {simWMA }}$ is shallower (around $50 \mathrm{~m}$ ). In the model outputs, the location of the DCM is roughly located at the nutrient-limiting nutricline, i.e., at the phosphacline depth in the WMA and sim ${ }^{\mathrm{WMA}}$, and at the nitracline depth in the WGY and $\operatorname{sim}^{\mathrm{WGY}}$. For both the data and the model outputs, we observe a difference in the depth of the DCM between the WMA and WGY, but no significant difference in the DCM intensity between the two regions. Nevertheless, there is a noticeable difference in the DCM intensity between observations and simulations: $\mathrm{Chl} a^{\text {obsWMA }}$ and $\mathrm{Chl} a^{\text {obsWGY }}$ maximum values are equal to $0.3 \mu \mathrm{gChl} \mathrm{L}{ }^{-1}$, while $\mathrm{Chl} a^{\text {simWMA }}$ and $\mathrm{Chl} a^{\text {simWGY }}$ maximum values are equal to $0.5 \mu \mathrm{gChl} \mathrm{L} \mathrm{L}^{-1}$. 

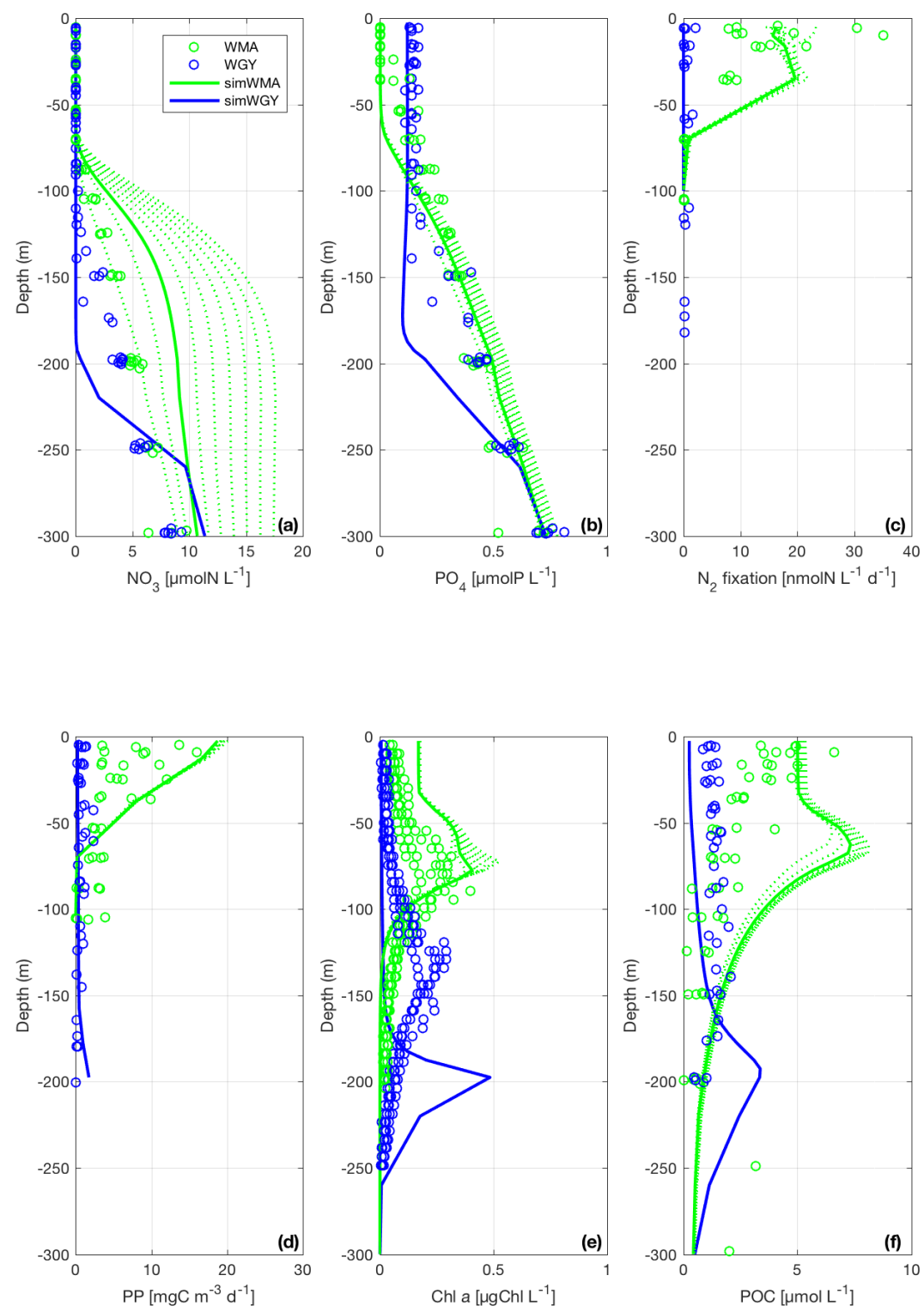

Figure 3. Vertical profiles of (a) dissolved inorganic nitrogen (DIN), (b) dissolved inorganic phosphorus (DIP), (c) $\mathrm{N}_{2}$ fixation rates, (d) primary production (PP), (e) chlorophyll $a(\mathrm{Chl} a$ ) and (f) particulate organic carbon (POC) during the OUTPACE cruise in the WMA region (green circles) and in the WGY region (blue circles), and from the model results of the simulation with diazotrophy as a proxy of the WMA region ( $\operatorname{sim}^{\mathrm{WMA}}$, green line) and without diazotrophy as a proxy of the WGY region ( $\operatorname{sim}^{\mathrm{WGY}}$, blue line). For the sim ${ }^{\mathrm{WMA}}$, we represent the profiles of the 10 years of simulation (dashed lines) to show the influence of the diazotrophy in the system.

The particulate carbon biomass (POC) presented in Fig. $3 \mathrm{f}$ shows significant differences between the WMA and WGY for both the data and the model results. First of all, there is a higher production of biomass at the WMA close to the surface than at the WGY. POC ${ }^{\text {obsWMA }}$ is, at the maximum, 5fold higher than $P O C^{\text {obsWGY }}$, with maximum values at the surface reaching $5 \mu \mathrm{M}$. POC ${ }^{\text {obsWMA }}$ then slightly decreases with depth to reach below $50 \mathrm{~m}$ values that are similar to those of POC ${ }^{\text {obsWGY }}$ (around 1.5 $\mu \mathrm{M}$ ). Higher simulated than measured POC values are also observed close to the surface.
A maximum value of $7.5 \mu \mathrm{M}$ for POC PimWMA $^{\text {correspond- }}$ ing to the DCM is found at $65 \mathrm{~m}$ but is not observed in in situ data. A 2.5-fold lower and deeper maximum is also observed in POC ${ }^{\text {simWGY }}$ just above $200 \mathrm{~m}$, with a maximum concentration of $3 \mu \mathrm{M}$. POC ${ }^{\text {simWGY }}$ concentrations remain very low between the surface and the deep maximum, while there is a significant POC production rate in simWMA, with POC $^{\text {simWMA }}$ concentrations higher than $6.5 \mu \mathrm{M}$ at the surface. 


\subsection{Seasonal variations}

Unlike the available in situ data, the model can provide the time variations of all the above-mentioned biogeochemical variables. The seasonal pattern of the nutrient pools, $\mathrm{N}_{2}$ fixation, Chl $a$ and POC is therefore shown over a 3-year period in order to focus on the seasonal variability. As already mentioned, the same atmospheric forcings are repeated every year, and they cover the period between the last winter mixing period before the OUTPACE cruise (September 2014) and the next winter in August 2015.

\subsubsection{Nutrient availability and $\mathbf{N}_{2}$ fixation dynamics}

The nutrient variations throughout the water column are in part related to the variations of the mixed layer depth (MLD) during the year. The seasonal variations of the MLD are plotted in Fig. 4a, b, $d$ and e. They clearly indicate a winter mixing beginning at the end of May leading to a maximum MLD of $70 \mathrm{~m}$ in August, followed by a longer stratified period from November to April, with a shallower (between 25 and $30 \mathrm{~m}$ ) MLD compared to winter mixing. Figure 4a shows the DIN concentrations for simWMA from the surface to $200 \mathrm{~m}$ on a logarithmic scale. There is a slight variation of the nitracline around $70 \mathrm{~m}$, but the concentration in the near-surface layer always remains below $3 \mathrm{nmol} \mathrm{L}^{-1}(\mathrm{nM})$, which is far below the quantification limit $(50 \mathrm{nM})$.

Unlike DIN, DIP presents significant seasonal variations throughout the year (Fig. 4b). The concentrations are also presented on a logarithmic scale using the Redfield ratio $($ DIP $\times 16)$ in order to easily compare DIN and DIP concentrations with respect to the "classical" proportion of phytoplankton biological demand. During winter mixing, surface DIP simWMA increases from 0.6 to $2 \mathrm{nM}$, and remains quite stable until the end of February before regularly decreasing until June down to $0.6 \mathrm{nM}$. DIP ${ }^{\text {simWMA }}$ then remains low during the stratified period until the next winter mixing in August. The phosphacline is always shallower than the nitracline in the simWMA and remains around $50 \mathrm{~m}$ depth.

Accounting for the huge computer memory this would require, the values of the different biogeochemical fluxes calculated by the model are not systematically saved. As a result, numerical values of fluxes are saved at a lower vertical resolution than concentrations (pools). For this reason we decided to represent the dynamics of $\mathrm{N}_{2}$ fixation at the surface (averaged over the first $10 \mathrm{~m}$ ) rather than as a function of depth, which would not have been as relevant as for the other variables. Figure $4 \mathrm{c}$ depicts the dynamics of the total $\mathrm{N}_{2}$ fixation as well as the respective contributions of Trichodesmium sp. and UCYN to this flux. The total $\mathrm{N}_{2}$ fixation at the surface varies from a minimum mean value of $15 \mathrm{nmol} \mathrm{L}^{-1} \mathrm{~d}^{-1}$ during the stratified period to a maximum mean value of $20 \mathrm{nmolL}^{-1} \mathrm{~d}^{-1}$ reached between July and August, i.e., during the winter mixing. The major contributor to the $\mathrm{N}_{2}$ fixation in simWMA is Trichodesmium sp., with on average a contribution of $80 \%$ of the total $\mathrm{N}_{2}$ fixed against $20 \%$ for the UCYN.

\subsubsection{Seasonal variations of surface chlorophyll $a$ and carbon biomass production}

Figure $4 \mathrm{~d}$ presents the Chl $a$ dynamics from the surface to $200 \mathrm{~m}$ depth, and shows clear seasonal variations in the photic layer throughout a year. Between October and April, the Chl $a^{\text {simWMA }}$ is quite homogenous from the surface to $70 \mathrm{~m}$, with a DCM around $50 \mathrm{~m}$ reaching a maximum concentration of $0.5 \mu \mathrm{gChl} \mathrm{L}{ }^{-1}$. From April and during the winter mixing, Chl $a^{\text {simWMA }}$ at the surface decreases rapidly, reaching concentrations below $0.15 \mu \mathrm{gChl} \mathrm{L}{ }^{-1}$. During the same period, there is also a deepening of the DCM toward $80 \mathrm{~m}$, associated with lower concentrations down to $0.4 \mu \mathrm{gChl} \mathrm{L}{ }^{-1}$.

The production of $\mathrm{C}$ biomass in simWMA shows significant seasonal variations in the photic layer (Fig. 4e). The period of maximum $\mathrm{C}$ production at the surface lasts from October to February, with maximum concentrations of POC ${ }^{\text {simWMA }}$ around $8 \mu \mathrm{M}$. As shown in Fig. 3f, a deep maximum peak of biomass is located at around $70 \mathrm{~m}$, with concentrations close to $9 \mu \mathrm{M}$. Like for Chl $a$, from the end of March and during the winter period, the surface POC ${ }^{\text {simWMA }}$ decreases significantly to reach concentrations 2-fold lower than those obtained during the bloom (i.e., between November and February). While POC ${ }^{\text {simWMA }}$ in the $0-50 \mathrm{~m}$ layer decreases during the stratified period, the deep maximum remains at the same depth, even if its intensity decreases with POC $^{\text {simWMA }}$ values at $70 \mathrm{~m}$, reaching a minimum value of $7 \mu \mathrm{M}$ at the end of July.

\section{Discussion}

The WTSP has been recently qualified as a hotspot of $\mathrm{N}_{2}$ fixation (Bonnet et al., 2017). It is hypothesized that, while flowing westward following the South Equatorial Current (SEC), the N-depleted, P-enriched waters from areas of denitrification located in the eastern Pacific meet in the western Pacific waters with sufficient iron to allow $\mathrm{N}_{2}$ fixation to occur (Moutin et al., 2008; Bonnet et al., 2017). In situ data showed an ecosystem significantly more productive in the WMA where $\mathrm{N}_{2}$ fixation rates were higher than in the WGY, where very low $\mathrm{N}_{2}$ fixation rates were measured. These contrasted areas raised the question of whether the diazotrophy could be responsible for these differences observed between the WMA and WGY, which led us to run two simulations that only differed by taking into account (i.e., simWMA), or not (i.e., simWGY), the process of diazotrophy. The results of these two simulations were compared to the observations collected at the WMA and WGY areas during the OUTPACE cruise (Fig. 3) in order to study the role of $\mathrm{N}_{2}$ fixation in sur- 

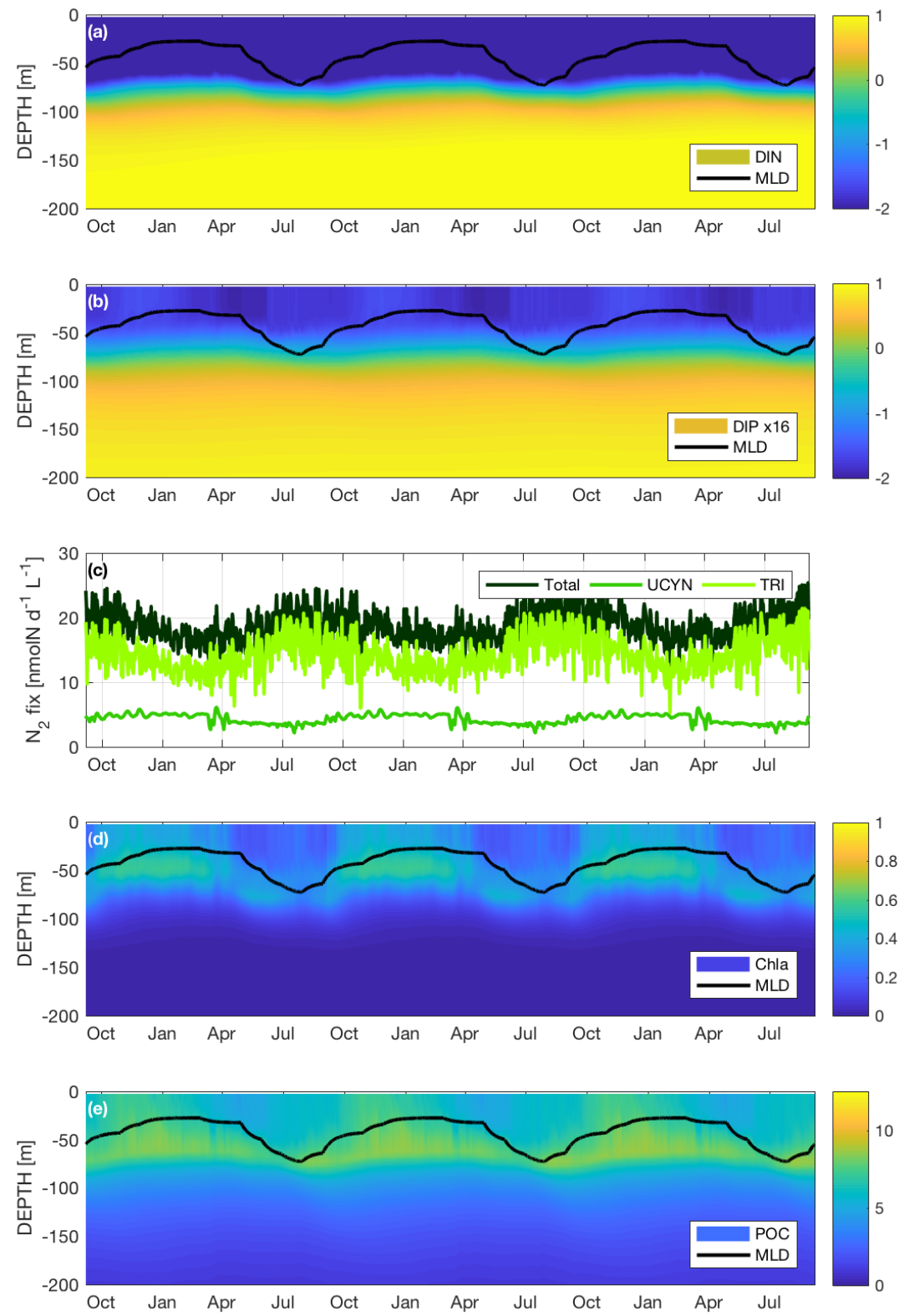

Figure 4. Seasonal dynamics of (a) dissolved inorganic nitrogen (DIN) on a logarithmic scale in $\mu \mathrm{M}$, (b) dissolved inorganic phosphorus $(\mathrm{DIP}) \times 16$ on a logarithmic scale in $\mu \mathrm{M}$, (c) surface $\mathrm{N}_{2}$ fixation rates in $\mathrm{nmol} \mathrm{L}^{-1} \mathrm{~d}^{-1}$, (d) chlorophyll $a(\mathrm{Chl} a)$ in $\mu \mathrm{gChl} \mathrm{L}-1$ and $(\mathbf{e})$ POC in $\mu \mathrm{M}$ for the simulation with diazotrophy, as a proxy of the WMA region ( $\operatorname{sim}^{\mathrm{WMA}}$ ) over 3 years.

face planktonic production and biogeochemical $\mathrm{C}, \mathrm{N}$, and $\mathrm{P}$ cycles.

\section{1 $\mathrm{N}_{2}$ fixation, closely linked to the DIP availability, enhances the surface production}

\subsubsection{Concomitant low DIP concentrations and high $\mathbf{N}_{2}$ fixation rates}

While DIN concentration remains below the quantification limit $(50 \mathrm{nM})$ everywhere in the surface layer, there is a sig- nificantly higher DIP concentration in the photic layer at the WGY than at the WMA in both the data and the model outputs (Fig. 3b). The relatively high DIP concentration in the WGY may be associated with inefficient or non-existent $\mathrm{N}_{2}$ fixation in the gyre (Moutin et al., 2018). Because of the high Fe requirement of diazotrophs (Paerl et al., 1987; Rueter et al., 1990), the low Fe availability in the WGY is assumed to prevent or significantly limit $\mathrm{N}_{2}$ fixation in the South Pacific Gyre (Moutin et al., 2008; Guieu et al., 2018; Moutin et al., 2018). By contrast, the high $\mathrm{Fe}$ availability in the WMA is assumed to favor the growth of nitrogen fixers. 
Guieu et al. (2018) indeed measured high DFe concentrations in the photic layer in the WMA provided by abnormally shallow hydrothermal sources (around $500 \mathrm{~m}$ deep) in the WTSP. Due to very low $\mathrm{N}_{2}$ fixation measured in the WGY (Bonnet et al., 2018), autotroph organisms are N-limited, leading to a lower PP than in the WMA, which results in a higher DIP accumulation in the photic layer since DIP is less consumed by organisms. Associated with lower DIP concentrations, higher $\mathrm{N}_{2}$ fixation rates are observed in the WMA in both the data and the model results (Fig. 3c). DIP depletion in simWMA is due to the presence of nitrogen fixers since the two simulations have exactly the same vertical dynamics and differ only by the presence/absence of nitrogen fixers.

Studies on the role of $\mathrm{N}_{2}$ fixation in the biogeochemistry of the Pacific Ocean have increased in number over the last decades, but the specific region of the WTSP remains patchily explored to date. Nevertheless, close to our studied area, Law et al. (2011) have observed a one-time DIP repletion in the surface layer due to a tropical cyclone which favored the upwelling of P-rich waters. On the basis of their Lagrangian strategy, they noticed a rapid consumption of this new DIP in correlation with a significant increase in the $\mathrm{N}_{2}$ fixation rates over the following 9 days. At a larger temporal scale, Karl et al. (1997) also observed a correlation between a decrease in DIP (about 50\%) and a significant increase in $\mathrm{N}_{2}$ fixation from 1989 to 1994, in the oligotrophic region of the subtropical North Pacific. The significant role of DIP availability in controlling $\mathrm{N}_{2}$ fixation in the oligotrophic iron-repleted WTSP (Van Den Broeck et al., 2004; Moutin et al., 2018) has been highlighted over the last decade (e.g., Moutin et al., 2005, 2008), and the consistent results between the OUTPACE data and our model outputs, comparing simWMA and simWGY, reinforce this view of the biogeochemical functioning of this region.

\subsubsection{Surface plankton productivity mainly driven by $\mathrm{N}_{2}$ fixation in the WSTP}

The patterns of surface production calculated by simWMA and simWGY are consistent (Fig. 3d): as with the in situ data, the model results show higher PP, POC and Chl $a$ in simWMA (i.e., with diazotrophy) than in simWGY (i.e., without diazotrophy) in the first $0-50 \mathrm{~m}$. PPsimWMA is 20 fold higher than PPsimWGY in the upper layer, in good agreement with PPobsWMA, which is 15-fold higher than PP obsWGY (Fig. 3d). Chl a concentrations never exceeding $0.5 \mu \mathrm{gChl} \mathrm{L} \mathrm{L}^{-1}$ are representative of oligotrophic waters. Model outputs and observations both show significantly deeper DCMs at the WGY than the WMA. The deepening of the DCM characterizes the transition from oligotrophic (WMA) to ultra-oligotrophic (WGY) conditions during the OUTPACE cruise (Moutin et al., 2018). In the model outputs, the difference between the DCM depth in simWMA and simWGY is larger than in in situ data: the DCM depth in simWGY is $150 \mathrm{~m}$ deeper than that of simWMA, whereas the observed DCM depth in the WMA is only $50 \mathrm{~m}$ deeper than that measured in the WMA. The simulation without diazotrophy indeed presents a DCM at $200 \mathrm{~m}$ depth, on average $50 \mathrm{~m}$ deeper than that observed in the WGY region (Fig. 3e). This deep DCM is consistent with the deep maxi-

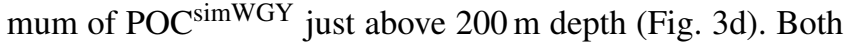
deep maxima are related to the nutricline depths located at 195 and $185 \mathrm{~m}$ for DIN ${ }^{\text {simWGY }}$ and DIP ${ }^{\text {simWGY }}$, respectively.

As with the DCM, the nutriclines in simWGY are significantly deeper than those measured in situ in the WGY. We assume that this gap is because $\mathrm{N}_{2}$ fixation is totally removed in simWGY, whereas low but existing $\mathrm{N}_{2}$ fixation still occurs in situ at the WGY (Fig. 3c). While the $\mathrm{N}_{2}$ fixation rates reported in the WGY were very low, Caffin et al. (2018) and Stenegren et al. (2018) mention the presence of such diazotrophs from the UCYN group, whereas no Trichodesmium sp. were found in this region. The in situ planktonic ecosystem in the WGY might therefore be slightly fueled by weak $\mathrm{N}_{2}$ fixation, which is not the case for simWGY since diazotrophy is not allowed. The above assumption concerning the gap between data and model outputs is consistent with the fact that the measured PP, POC and Chl $a$ in the WGY are always slightly higher than in the model outputs for the surface layer (Fig. 3d, e and f). To support this assumption, we ran another simulation considering only the presence of UCYN as diazotrophs in the WGY. The results of this intermediate simulation (not shown) indicate low surface PP rates and POC concentrations, in agreement with those measured in the WGY. Moreover, DIP is still available in the photic zone (though at concentrations lower than for simWGY) even if the calculated $\mathrm{N}_{2}$ fixation rates were slightly higher than the measured ones. In addition, the DCM (located around $150 \mathrm{~m}$ ) and the nutriclines were shallower than in simWGY (i.e., without any diazotrophs). This simulation can thus be considered like an intermediate system between simWMA and simWGY, and confirms the close link between $\mathrm{N}_{2}$ fixation fluxes and DIP availability.

In a previous study using nearly the same biogeochemical model including TRI and UCYN state variables in a one-dimensional configuration without physical coupling, Gimenez et al. (2016) highlighted the direct and indirect impact of the new $\mathrm{N}$ input provided by diazotrophs. By calculating the percentage of diazotroph-derived nitrogen (DDN) in each model compartment, they followed the transfer of DDN throughout the entire trophic web as a function of time, and showed that after 25 days, $43 \%$ of the DDN fixed by diazotrophs was found in non-diazotroph organisms. These results clearly showed that $\mathrm{N}_{2}$ fixation had a significant indirect impact on the planktonic production by providing a new source of $\mathrm{N}$ for other organisms. DDN tracking inside the model compartments is associated with very high computational costs and could not be applied to the present study, where simulations are run for several years (against 25 days for the previous study). However, it is worthwhile mentioning that the proportion of PFTs involved in total Chl $a$ and 

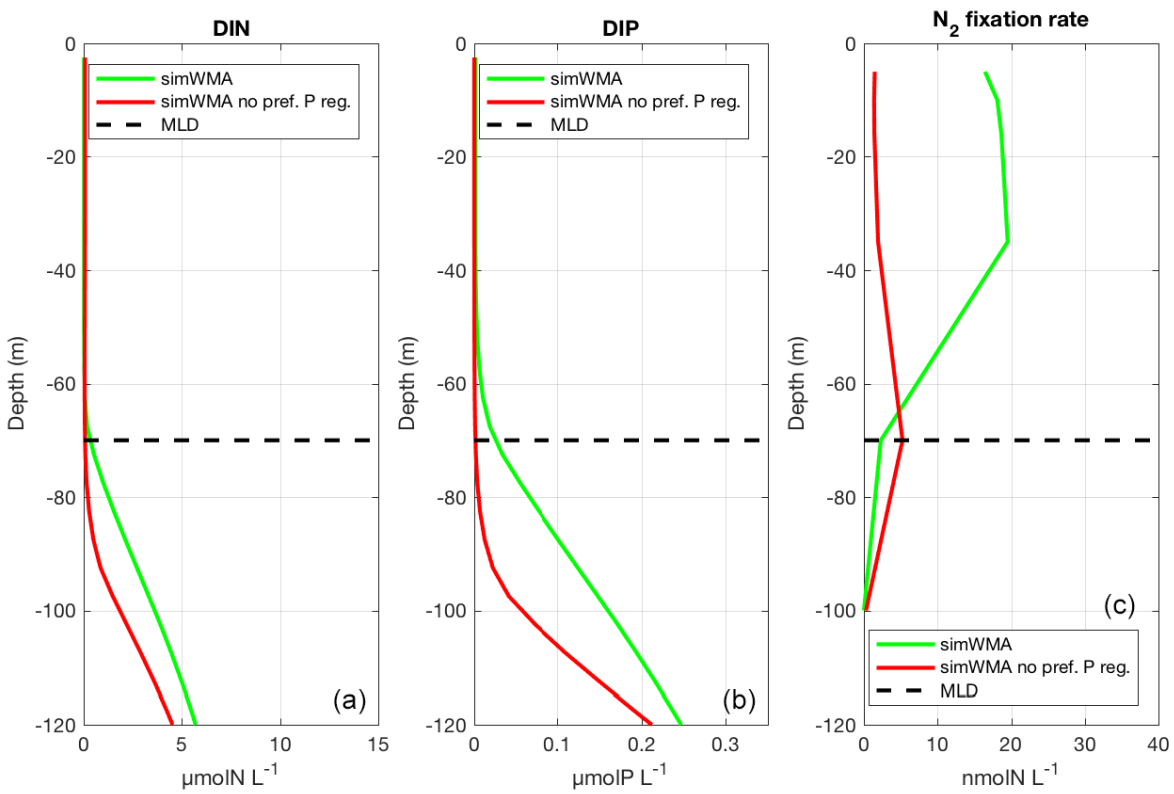

Figure 5. Vertical profiles of (a) dissolved inorganic nitrogen (DIN), (b) dissolved inorganic phosphorus (DIP), and (c) $\mathrm{N}_{2}$ fixation rates for the simulation with diazotrophy, as a proxy of the WMA region ( $\operatorname{sim}^{\mathrm{WMA}}$ ) with the preferential P regeneration (in green) and without the preferential $\mathrm{P}$ regeneration (in red). The horizontal black dashed line represents the depth of the maximum mixed layer calculated at $70 \mathrm{~m}$ depth.

PP was $80 \%$ of TRI, $10 \%$ of PHYS and $5 \%$ of UCYN and PHYL, suggesting that the impact of $\mathrm{N}_{2}$ fixation is direct (85\% of PP is realized by diazotrophs) rather than indirect. In our model, diazotrophs have therefore a net competitive advantage over the two other non-diazotrophic autotrophs.

\subsection{A close link between MLD, nutricline depth and $\mathrm{N}_{2}$ fixation}

\subsubsection{How can the nutricline depths influence $\mathrm{N}_{2}$ fixation?}

In such oligotrophic areas, the positions of the nutriclines are crucial in controlling surface production (Behrenfeld et al., 2006; Cermeño et al., 2008) as they provide nutrients from the bottom to the photic layer. The equatorial Pacific Ocean is known for its complex hydrodynamic circulation induced by constant trade winds, leading to significant variations in the thermocline position between the east and the west of the basin (Meyers, 1979). Trade winds also have an influence on the nutrient availability in the surface layer (Radenac and Rodier, 1996; Zhang et al., 2007).

During OUTPACE, the phosphacline (above $50 \mathrm{~m}$ ) appeared shallower than the nitracline (about $75 \mathrm{~m}$ ) in the WMA region (Fig. 3a and b). A similar shift between nitracline and phosphacline depths was observed $10^{\circ}$ further south than our studied area, with a nitracline about $20 \mathrm{~m}$ deeper than the phosphacline (Law et al., 2011). In those $\mathrm{N}$-depleted regions, diazotrophs may outcompete non- diazotroph organisms, using the unlimited atmospheric $\mathrm{N}_{2}$ (Agawin et al., 2007; Dutkiewicz et al., 2014). However, their development also requires sufficient light intensity and other nutrients such as $\mathrm{P}$ and $\mathrm{Fe}$, and the debate on their expected limitation or co-limitation is of great interest to the ocean biogeochemical community (Falkowski, 1997; Wu et al., 2000; Sañudo-Wilhelmy et al., 2001; Mills et al., 2004; Moutin et al., 2005; Monteiro et al., 2011).

On the basis of our model, we understood that it was crucial to take into account the nutricline depths, and that a shallower phosphacline than nitracline was needed to observe $\mathrm{N}_{2}$ fixation rates in agreement with those measured in situ (Fig. 3c). This led us to implement a preferential $\mathrm{P}$ regeneration in our model to reproduce the shift between the nitracline and the phosphacline (see Sect. 4.2.2 for more details). In our preliminary results (red lines in Fig. 5), without this decoupling, the depths of the nitracline and phosphacline were located at the same depth (around $80 \mathrm{~m}$ ), and below the MLD (Fig. 5a and b). Each winter, mixing brought low concentrations of DIN and DIP into the euphotic layer. Low DIN concentrations are favorable for the development of $\mathrm{N}_{2}$ fixers (Holl and Montoya, 2008; Agawin et al., 2007), but they were rapidly limited by DIP availability as the winter mixing did not provide enough DIP in the photic layer, leading to very low $\mathrm{N}_{2}$ fixation rates (Fig. 5c). In this configuration, primary production was $\mathrm{N}$-limited and low compared to what was observed in the WMA region. The phosphacline had to be shallower (here about $25 \mathrm{~m}$ ) than the nitracline, and above the winter MLD $(70 \mathrm{~m})$, to counteract DIP limitation. In this 
case, no DIN is brought by winter mixing into the photic layer, which favors $\mathrm{N}_{2}$ fixers compared to non-fixer organisms, and sufficient DIP concentrations to support surface production until the next winter mixing. This simWMA configuration led to a significant development of $\mathrm{N}_{2}$ fixers in the 0-50 m layer, dominated by Trichodesmium sp. (not shown), with consistent rates of $\mathrm{N}_{2}$ fixation and PP rates (Fig. 3c and d).

\subsubsection{A preferential $P$ regeneration needed to sustain $\mathbf{N}_{2}$ fixation}

To obtain with the model a phosphacline shallower than the nitracline, and thereby decrease DIP depletion in the surface layer, we had to decouple the regeneration of the detrital organic particulate N (DET-N) and the detrital particulate organic P (DET-P) by significantly increasing the remineralization rate of DET-P compared to that of DET-N and DET-C. The use of extracellular phosphoenzymes (e.g., alkaline phosphatase, nucleotidase, polyphosphatase or phosphodiesterase) by microorganisms to regenerate DIP from dissolved organic P when DIP is depleted is well known (Perry, 1972, 1976; Vidal et al., 2003). Our model does not include the explicit phosphatase alkaline activity, but it is represented indirectly by giving direct access to DOP by autotrophs. However, this advantage was not sufficient to decrease P limitation enough and allow the growth of $\mathrm{N}_{2}$ fixers so as to calculate $\mathrm{N}_{2}$ fixation rates consistent with those measured in the WMA. A preferential $P$ regeneration of the particulate organic matter was required and obtained by increasing the DET-P hydrolysis rate compared to that of DET-C and DET$\mathrm{N}$. The location of the detrital matter regeneration in the water column is based on a balance between the sinking and the hydrolysis rates of the particulate organic matter. As mentioned in Sect. 4.2.2, the detrital matter is divided into two size fractions associated with two constant sinking rates of 1.0 and $25.0 \mathrm{~m} \mathrm{~d}^{-1}$ for the small and large detrital particulate matter, respectively. Initially, the hydrolysis rates for the detrital $\mathrm{C}, \mathrm{N}$ and $\mathrm{P}$ particulate matter were the same, and equal to $0.05 \mathrm{~d}^{-1}$. The preferential regeneration of $P$ was a posteriori obtained by increasing the hydrolysis rate of particulate $\mathrm{P}$ to $2.0 \mathrm{~d}^{-1}$, without any change in the sinking rates. To illustrate how the discrepancy between nitracline and phosphacline depths can be attributed to preferential $P$ regeneration, DIN and DIP concentrations and $\mathrm{N}_{2}$ fixation rates in simWMA calculated with and without preferential $P$ regeneration (i.e., preferential hydrolysis of $\mathrm{P}$ particulate matter) have been compared (Fig. 5). This figure shows the deepening of the phosphacline in the simulation without preferential $\mathrm{P}$ regeneration. More importantly, without preferential $\mathrm{P}$ regeneration, the phosphacline depth is deeper than the MLD at $70 \mathrm{~m}$, which prevents DIP input in the surface layer during winter mixing, and leads to a strong limitation of diazotrophs by $\mathrm{P}$. This stronger $\mathrm{P}$ limitation without preferential $\mathrm{P}$ regeneration can also be observed at the cellular scale by analyz- ing the intracellular $\mathrm{P}$ quota of $\mathrm{N}_{2}$ fixers. In the simulation without preferential $\mathrm{P}$ regeneration, the relative intracellular quota of P in TRI and UCYN is on average, respectively, 8 and 16 times lower than with preferential $P$ regeneration. As $\mathrm{N}_{2}$ fixation alleviates $\mathrm{N}$ limitation for diazotrophs, their growth is limited by $\mathrm{P}$ availability. The significant decrease in relative intracellular $\mathrm{P}$ quotas has therefore a significant impact on their growth, and consequently explains the lower $\mathrm{N}_{2}$ fixation rates shown in Fig. 5c. This preferential P remineralization was also used by Zamora et al. (2010), who investigated different mechanisms that might be able to explain the $\mathrm{N}$ excess observed in the North Atlantic main thermocline. Even if their model did not include $\mathrm{N}_{2}$ fixation, they concluded that the $\mathrm{N}$ excess observed would be a consequence of a co-occurrence of a preferential $\mathrm{P}$ remineralization and a surface $\mathrm{N}$ input provided by $\mathrm{N}_{2}$ fixation. With the same aim of studying the $\mathrm{N}$ excess observed in the North Atlantic main thermocline, Coles and Hood (2007) implemented a more complex model including the $\mathrm{N}_{2}$ fixation process and variable stoichiometry for the non-living compartments. They concluded that a preferential $\mathrm{P}$ regeneration was needed to generate the $\mathrm{N}$ excess anomalies observed in the subsurface North Atlantic, and the preferential $\mathrm{P}$ regeneration was obtained by increasing the $\mathrm{P}$ remineralization rates relative to $\mathrm{N}$. In both their and our study, the change in P remineralization rate was necessary to reduce upper surface $\mathrm{P}$ limitation for diazotrophs and to obtain $\mathrm{N}_{2}$ fixation rates consistent with observations.

\section{3 $\mathrm{N}$ from $\mathrm{N}_{2}$ fixation accumulates in the main thermocline}

By running the model simulations over 10 years, we observed the storage of the $\mathrm{N}$ input by diazotrophy. The nitrate accumulation observed in simWMA from 70 to $500 \mathrm{~m}$ (Fig. 3a), reaching concentrations of $17.0 \mu \mathrm{M}$ after a run of 10 years, is obviously overestimated as we used a onedimensional model, without any horizontal exchange. The horizontal advection which would occur in the field is not represented here, and without any loss processes taken into account, the annual $\mathrm{N}$ input by $\mathrm{N}_{2}$ fixation accumulates, as observed in simWMA. The interesting point is the location of this accumulation around the first $400 \mathrm{~m}$ of the main thermocline between 100 and $500 \mathrm{~m}$ depth. This result is consistent with some studies which have investigated the $\mathrm{N}$ excess in the ocean, using for instance the $\mathrm{N}^{\star}$ tracer $\left(\mathrm{N}^{\star}=\mathrm{NO}_{3}^{-}-16 \times \mathrm{PO}_{4}^{3-}\right.$, Gruber and Sarmiento, 1997) and the $\mathrm{N}_{2}$ fixation contribution to this $\mathrm{N}$ excess (Bates and Hansell, 2004; Hansell et al., 2004; Landolfi et al., 2008; Zamora et al., 2010). A companion paper in this special issue investigates in detail the $\mathrm{N}$ excess observed in the WTSP in relation to $\mathrm{N}_{2}$ fixation (Fumenia et al., 2018). Our model results clearly show an accumulation of $\mathrm{N}$ in the $100-500 \mathrm{~m}$ layer which results from the new $\mathrm{N}$ input by diazotrophy, as this is the sole external $\mathrm{N}$ source implemented. This accu- 
mulation constantly increases every year by an average of 449.6 mmolN m ${ }^{-2}$, while the annual integrated $\mathrm{N}_{2}$ fixation provides $451.0 \mathrm{mmolN} \mathrm{m}^{-2}$. After benefiting the upper water ecosystem, more than $99.5 \%$ of new $\mathrm{N}$ derived from $\mathrm{N}_{2}$ fixation ends in the DIN pool from the 100-500 m layer. We use a one-dimensional model which is not intended to provide any quantitative conclusion regarding this $\mathrm{N}$ accumulation, but these calculations explain the annual DIN accumulation observed in Fig. 3a. According to the model, $\mathrm{N}_{2}$ fixation may explain the $\mathrm{N}$ excess observed in situ around the main thermocline in the WTSP, as reported by Fumenia et al. (2018).

\section{4 $\mathrm{N}_{2}$ fixation leading to seasonal variations in the WTSP}

To date, the WTSP, and more generally the South Pacific Ocean, has been much less studied than the North Pacific Ocean, which has been sampled since the late 1980 s within the framework of the Long-term Oligotrophic Habitat Assessment (ALOHA) near the Hawaii islands. The South Pacific has been sampled from west to east during the BIOSOPE (Claustre et al., 2008) and OUTPACE (Moutin et al., 2017) French oceanographic cruises and many other cruises (e.g., Moisander et al., 2012, as well as the cruises involved in the GLODAPv2 project, Olsen et al., 2016), providing a spatial (Fumenia et al., 2018) but not temporal overview of the southern tropical Pacific. To date, the seasonal variations have only been studied during the DIAPALIS cruises (http://www.obs-vlfr.fr/proof/vt/ op/ec/diapazon/dia.htm, last access: 8 October 2018) in several stations located in the MA close to New Caledonia. By means of our one-dimensional model, we can analyze the annual variability of the entire ecosystem implemented in the model in order to corroborate, or not, certain hypotheses raised from the OUTPACE data analysis.

Seasonal variations obtained in sim ${ }^{\text {WMA }}$ (Fig. 4) allow us to trace the annual "history" of the WMA region: during the winter period, vertical mixing intensifies and replenishes the surface layer in DIP but not in DIN, as the nitracline is deeper than the MLD (70 m), whereas the phosphacline is shallower (Fig. 3a and b). The newly available DIP in the surface layer is immediately followed by an increase in $\mathrm{N}_{2}$ fixation rates in June (Fig. 3c), which then remain quite stable until October before slightly decreasing until the next winter mixing. There is a close relationship between DIP availability and the $\mathrm{N}_{2}$ fixation rates since $\mathrm{N}_{2}$ fixation decreases as the DIP concentration decreases with the DIP's gradual consumption after the mixing period. Because $\mathrm{N}_{2}$ fixation provides a new source of $\mathrm{N}$ (characterized by a rapid turnover time, as it is immediately used and transferred into the ecosystem), the DIP is consumed, thereby generating seasonal variations in the surface layer. Although autotrophs are dominated by $\mathrm{N}_{2}$ fixers, $\mathrm{N}_{2}$ fixation benefits the entire planktonic trophic web and enhances the surface production which is directly controlled by nutrient availability. We therefore observe surface seasonal variations in $\mathrm{Chl} a^{\text {simWMA }}$ and POC ${ }^{\text {simWMA }}$, with maximum values from October to the end of March, and a less intense and deeper signal around $70 \mathrm{~m}$ (which corresponds to the nitracline depth from April to the end of May). During the stratified period, when $\mathrm{N}_{2}$ fixation is lowest, nondiazotroph organisms grow deeper where DIN is available. The temporal evolution of simWGY is not shown here as there is no seasonal variation associated with $\mathrm{N}_{2}$ fixation, which is the focus of the study presented here. The absence of diazotrophy leads to a deepening of the nitracline and available DIN is deeper. DIP is never exhausted in the surface layer because the model implicitly assumes iron limitation to prevent $\mathrm{N}_{2}$ fixation. The maximum biomass and DCM are constant throughout the year, significantly less intense than in simWMA and located near the nitracline around $200 \mathrm{~m}$.

\section{Conclusions}

The purpose of this study was to investigate the direct and/or indirect role of $\mathrm{N}_{2}$ fixation in surface planktonic production and biogeochemical $\mathrm{C}, \mathrm{N}$, and $\mathrm{P}$ cycles, with the aim of determining whether the main biogeochemical differences observed in the MA and in the SPG areas could be explained or not by diazotrophy. For this purpose, a new coupled one-dimensional physical-biogeochemical model has been built based on the Eco3M-Med model. Two simulations were designed, only differing by the presence/absence of diazotrophs. They enabled us to reasonably reproduce the main biogeochemical characteristics of the two areas (WMA and WGY). The model could also reproduce the high contrast between the two regions, such as (i) the high/low DIP availability, respectively, associated with significant/negligible $\mathrm{N}_{2}$ fixation and surface production, (ii) the higher/lower depth of the nutriclines characteristic of oligotrophic (WMA)/ultraoligotrophic (WGY) regions, and (iii) the large/small gap between DIN and DIP nutriclines and the subsequent consequences for nutrient input in the surface layer during winter mixing.

Winter mixing allows the annual replenishment of the surface layer in excess $\mathrm{P}$, creating ideal conditions for diazotroph growth and intensive $\mathrm{N}_{2}$ fixation. The development of diazotrophs can counteract DIN limitation for the entire planktonic trophic web in the photic layer in the WMA, which leads to significant seasonal variations due to the progressive exhaustion of DIP after winter mixing. Throughout the year, we then showed a shift from $\mathrm{N}$ to $\mathrm{P}$ limitation of the planktonic community growth in the MA. The strong influence of seasonal variations shown by the simulations in the WTSP, and generally not considered in tropical areas, needs to be further studied and backed up by in situ observations.

Data availability. All data and metadata are available at the French INSU/CNRS LEFE CYBER database (scientific coordinator: Hervé 
Claustre; data manager, webmaster: Catherine Schmechtig) at the following web address: http://www.obs-vlfr.fr/proof/php/outpace/ outpace.php, INSU/CNRS LEFE CYBER (2017).

Supplement. The supplement related to this article is available online at: https://doi.org/10.5194/bg-15-6573-2018-supplement.

Competing interests. The authors declare that they have no conflict of interest.

Special issue statement. This article is part of the special issue "Interactions between planktonic organisms and biogeochemical cycles across trophic and $\mathrm{N}_{2}$ fixation gradients in the western tropical South Pacific Ocean: a multidisciplinary approach (OUTPACE experiment)". It is not associated with a conference.

Acknowledgements. This is a contribution of the OUTPACE (Oligotrophy from Ultra-oligoTrophy PACific Experiment) project (https://outpace.mio.univ-amu.fr/, last access: 8 October 2018) funded by the French research national agency (ANR-14-CE01-0007-01), the LEFE-CyBER program (CNRSINSU), the GOPS program (IRD), the CNES, and the European FEDER Fund under project 1166-39417. The OUTPACE cruise (https://doi.org/10.17600/15000900) was managed by the MIO (OSU Institut Pytheas, AMU) from Marseilles (France). The authors thank the crew of the R/V L'Atalante for outstanding shipboard operation. Gilles Rougier and Marc Picheral are warmly thanked for their efficient help in CTD rosette management and data processing, as is Catherine Schmechtig for the LEFE CYBER database management. The authors also acknowledge the staff of the "Cluster de calcul intensif HPC" platform of the OSU Institut Pythéas (Aix-Marseille Université, INSU-CNRS) for providing the computing facilities. Finally, the authors gratefully acknowledge Maurice Libes and Christophe Yohia from the Service Informatique de Pythéas (SIP) for technical assistance and for providing the atmospheric forcings for the present modeling study.

Edited by: Laurent Mémery

Reviewed by: two anonymous referees

\section{References}

Agawin, N. S., Rabouille, S., Veldhuis, M. J., Servatius, L., Hol, S., van Overzee, H. M., and Huisman, J.: Competition and facilitation between unicellular nitrogen-fixing cyanobacteria and non-nitrogen-fixing phytoplankton species, Limnol. Oceanogr., 52, 2233-2248, 2007.

Alekseenko, E., Raybaud, V., Espinasse, B., Carlotti, F., Queguiner, B., Thouvenin, B., Garreau, P., and Baklouti, M.: Seasonal dynamics and stoichiometry of the planktonic community in the NW Mediterranean Sea; a 3D modeling approach, Ocean Dynam., 64, 179-207, 2014.
Baklouti, M., Faure, V., Pawlowski, L., and Sciandra, A.: Investigation and sensitivity analysis of a mechanistic phytoplankton model implemented in a new modular numerical tool (Eco3M) dedicated to biogeochemical modelling, Prog. Oceanogr., 71, 34-58, https://doi.org/10.1016/j.pocean.2006.05.003, 2006.

Bates, N. R. and Hansell, D. A.: Temporal variability of excess nitrate in the subtropical mode water of the North Atlantic Ocean, Marine Chem., 84, 225-241, https://doi.org/10.1016/j.marchem.2003.08.003, 2004.

Behrenfeld, M. J., O’Malley, R. T., Siegel, D. A., McClain, C. R., Sarmiento, J. L., Feldman, G. C., Milligan, A. J., Falkowski, P. G., Letelier, R. M., and Boss, E. S.: Climate-driven trends in contemporary ocean productivity, Nature, 444, 752-755, https://doi.org/10.1038/nature05317, 2006.

Benavides, M., Agawin, N., Aristegui, J., Penne, J., and Stal, L.: Dissolved organic nitrogen and carbon release by a marine unicellular diazotrophic cyanobacterium, Aquat. Microb. Ecol., 69, 69-80, 2013.

Berthelot, H., Bonnet, S., Camps, M., Grosso, O., and Moutin, T.: Assessment of the dinitrogen released as ammonium and dissolved organic nitrogen by unicellular and filamentous marine diazotrophic cyanobacteria grown in culture, Front. Mar. Sci., 2, 80, https://doi.org/10.3389/fmars.2015.00080, 2015.

Bonnet, S., Caffin, M., Berthelot, H., and Moutin, T.: Hot spot of N2 fixation in the western tropical South Pacific pleads for a spatial decoupling between $\mathrm{N} 2$ fixation and denitrification, P. Natl. Acad. Sci., 114, E2800-E2801, https://doi.org/10.1073/pnas.1619514114, 2017.

Bratbak, G.: Bacterial Biovolume and Biomass Estimations, Appl. Environ. Microbiol., 49, 1488-1493, 1985.

Bronk, D. A. and Ward, B. B.: Magnitude of dissolved organic nitrogen release relative to gross nitrogen uptake in marine systems, Limnol. Oceanogr., 45, 1879-1883, https://doi.org/10.4319/lo.2000.45.8.1879, 2000.

Caffin, M., Moutin, T., Foster, R. A., Bouruet-Aubertot, P., Doglioli, A. M., Berthelot, H., Guieu, C., Grosso, O., Helias-Nunige, S., Leblond, N., Gimenez, A., Petrenko, A. A., de Verneil, A., and Bonnet, $\mathrm{S}$.: $\mathrm{N}_{2}$ fixation as a dominant new $\mathrm{N}$ source in the western tropical South Pacific Ocean (OUTPACE cruise), Biogeosciences, 15, 2565-2585, https://doi.org/10.5194/bg-152565-2018, 2018.

Capone, D. G., Zehr, J. P., Paerl, H. W., Bergman, B., and Carpenter, E. J.: Trichodesmium, a globally significant marine cyanobacterium, Science, 276, 1221-1229, 1997.

Capone, D. G., Burns, J. A., Montoya, J. P., Subramaniam, A., Mahaffey, C., Gunderson, T., Michaels, A. F., and Carpenter, E. J.: Nitrogen fixation by Trichodesmium spp.: An important source of new nitrogen to the tropical and subtropical North Atlantic Ocean, Global Biogeochem. Cy., 19, GB2024, https://doi.org/10.1029/2004GB002331, 2005.

Cermeño, P., Dutkiewicz, S., Harris, R. P., Follows, M., Schofield, O., and Falkowski, P. G.: The role of nutricline depth in regulating the ocean carbon cycle, P. Natl. Acad. Sci., 105, 20344 20349, https://doi.org/10.1073/pnas.0811302106, 2008.

Claustre, H., Sciandra, A., and Vaulot, D.: Introduction to the special section bio-optical and biogeochemical conditions in the South East Pacific in late 2004: the BIOSOPE program, Biogeosciences, 5, 679-691, https://doi.org/10.5194/bg-5-6792008, 2008. 
Coles, V. J. and Hood, R. R.: Modeling the impact of iron and phosphorus limitations on nitrogen fixation in the Atlantic Ocean, Biogeosciences, 4, 455-479, https://doi.org/10.5194/bg-4-4552007, 2007.

Cotner, J. B., Hall, E. K., Scott, T., and Heldal, M.: Freshwater Bacteria are Stoichiometrically Flexible with a Nutrient Composition Similar to Seston, Front. Microbiol., 1, https://doi.org/10.3389/fmicb.2010.00132, 2010.

de Baar, H. J. W.: Von Liebig's law of the minimum and plankton ecology (1899-1991), Prog. Oceanogr., 33, 347-386, https://doi.org/10.1016/0079-6611(94)90022-1, 1994.

de Verneil, A., Rousselet, L., Doglioli, A. M., Petrenko, A. A., Maes, C., Bouruet-Aubertot, P., and Moutin, T.: OUTPACE long duration stations: physical variability, context of biogeochemical sampling, and evaluation of sampling strategy, Biogeosciences, 15, 2125-2147, https://doi.org/10.5194/bg-15-2125-2018, 2018.

Dutheil, C., Aumont, O., Gorguès, T., Lorrain, A., Bonnet, S., Rodier, M., Dupouy, C., Shiozaki, T., and Menkes, C.: Modelling $\mathrm{N}_{2}$ fixation related to Trichodesmium sp.: driving processes and impacts on primary production in the tropical Pacific Ocean, Biogeosciences, 15, 4333-4352, https://doi.org/10.5194/bg-154333-2018, 2018.

Dutkiewicz, S., Ward, B. A., Scott, J. R., and Follows, M. J.: Understanding predicted shifts in diazotroph biogeography using resource competition theory, available at: http://dspace.mit.edu/ handle/1721.1/92505 (last access: 4 October 2018), 2014.

Falkowski, P. G.: Evolution of the nitrogen cycle and its influence on the biological sequestration of $\mathrm{CO}_{2}$ in the ocean, Nature, 387 , 272-275, https://doi.org/10.1038/387272a0, 1997.

Falkowski, P. G., Barber, R. T., and Smetacek, V.: Biogeochemical controls and feedbacks on ocean primary production, Science, 281, 200-206, 1998.

Fennel, K., Spitz, Y. H., Letelier, R. M., Abbott, M. R., and Karl, D. M.: A deterministic model for $\mathrm{N}_{2}$ fixation at stn. ALOHA in the subtropical North Pacific Ocean, Deep Sea Res. Pt. II, 49, 149-174, 2002.

Fumenia, A., Moutin, T., Bonnet, S., Benavides, M., Petrenko, A., Helias Nunige, S., and Maes, C.: Excess nitrogen as a marker of intense dinitrogen fixation in the Western Tropical South Pacific Ocean: impact on the thermocline waters of the South Pacific, Biogeosciences Discuss., https://doi.org/10.5194/bg-2017557, in review, 2018.

Gaspar, P.: Modeling the Seasonal Cycle of the Upper Ocean, J. Phys. Oceanogr., 18, 161-180, https://doi.org/10.1175/15200485(1988)018<0161:MTSCOT>2.0.CO;2, 1988.

Gaspar, P., Grégoris, Y., and Lefevre, J.-M.: A simple eddy kinetic energy model for simulations of the oceanic vertical mixing: Tests at station Papa and long-term upper ocean study site, J. Geophys. Res., 95, 16179, https://doi.org/10.1029/JC095iC09p16179, 1990.

Gimenez, A., Baklouti, M., Bonnet, S., and Moutin, T.: Biogeochemical fluxes and fate of diazotroph-derived nitrogen in the food web after a phosphate enrichment: modeling of the VAHINE mesocosms experiment, Biogeosciences, 13, 51035120, https://doi.org/10.5194/bg-13-5103-2016, 2016.

Goldman, J. C. and Dennett, M. R.: Growth of marine bacteria in batch and continuous culture under carbon and nitrogen limitation, Limnol. Oceanogr., 45, 789-800, https://doi.org/10.4319/1o.2000.45.4.0789, 2000.
Grimaud, G. M., Dron, A., Rabouille, S., Sciandra, A., and Bernard, O.: Modelling light-dark regime influence on the carbon-nitrogen metabolism in a unicellular diazotrophic cyanobacterium, in: CAB, available at: http://hal.upmc.fr/hal-00854479 (last access: 8 October 2018), 2013.

Gruber, N.: The dynamics of the marine nitrogen cycle and its influence on atmospheric $\mathrm{CO}_{2}$ variations, in: The ocean carbon cycle and climate, 97-148, Springer, 2004.

Gruber, N. and Sarmiento, J. L.: Global patterns of marine nitrogen fixation and denitrification, Global Biogeochem. Cy., 11, 235266, https://doi.org/10.1029/97GB00077, 1997.

Guieu, C., Bonnet, S., Petrenko, A., Menkes, C., Chavagnac, V., Desboeufs, K., Maes, C., and Moutin, T.: Iron from a submarine source impacts the productive layer of the Western Tropical South Pacific (WTSP), Scientific Reports, 8, 9075, https://doi.org/10.1038/s41598-018-27407-z, 2018.

Hansell, D. A., Bates, N. R., and Olson, D. B.: Excess nitrate and nitrogen fixation in the North Atlantic Ocean, Marine Chem., 84, 243-265, https://doi.org/10.1016/j.marchem.2003.08.004, 2004.

Holl, C. M. and Montoya, J. P.: Diazotrophic growth of the marine yanobacterium Trichodesmium Ims101 in continuous culture: effects of growth rate on $\mathrm{N}_{2}$-fixation rate, biomass, and C:N:P stoichiometry, J. Phycol., 44, 929-937, https://doi.org/10.1111/j.1529-8817.2008.00534.x, 2008.

Hutchins, D. A., Fu, F.-X., Zhang, Y., Warner, M. E., Feng, Y., Portune, K., Bernhardt, P. W., and Mulholland, M. R.: CO2 control of Trichodesmium N2 fixation, photosynthesis, growth rates, and elemental ratios: Implications for past, present, and future ocean biogeochemistry, Limnol. Oceanogr., 52, 1293-1304, https://doi.org/10.4319/lo.2007.52.4.1293, 2007.

Karl, D. and Letelier, R.: Nitrogen fixation-enhanced carbon sequestration in low nitrate, low chlorophyll seascapes, Mar. Ecol. Prog. Ser., 364, 257-268, https://doi.org/10.3354/meps07547, 2008.

Karl, D., Letelier, R., Tupas, L., Dore, J., Christian, J., and Hebel, D.: The role of nitrogen fixation in biogeochemical cycling in the subtropical North Pacific Ocean, Nature, 388, 533-538, https://doi.org/10.1038/41474, 1997.

Karl, D., Michaels, A., Bergman, B., Capone, D., Carpenter, E., Letelier, R., Lipschultz, F., Paerl, H., Sigman, D., and Stal, L.: Dinitrogen fixation in the world's oceans, Biogeochemistry, 5758, 47-98, https://doi.org/10.1023/A:1015798105851, 2002.

Landolfi, A., Oschlies, A., and Sanders, R.: Organic nutrients and excess nitrogen in the North Atlantic subtropical gyre, Biogeosciences, 5, 1199-1213, https://doi.org/10.5194/bg-5-11992008, 2008.

Law, C. S., Woodward, E. M. S., Ellwood, M. J., Marriner, A., Bury, S. J., and Safi, K. A.: Response of surface nutrient inventories and nitrogen fixation to a tropical cyclone in the southwest Pacific, Limnol. Oceanogr., 56, 1372-1385, https://doi.org/10.4319/lo.2011.56.4.1372, 2011.

Locarnini, R. A., Mishonov, A. V., Antonov, J. I., Boyer, T. P., Garcia, H. E., Baranova, O. K., Zweng, M. M., Paver, C. R., Reagan, J. R., Johnson, D. R., Hamilton, M., and Seidov, D.: World ocean atlas 2013. Volume 1, Temperature, Tech. rep., NOAA Atlas NESDIS 73, https://doi.org/10.7289/V55X26VD, 2013.

Luo, Y.-W., Doney, S. C., Anderson, L. A., Benavides, M., BermanFrank, I., Bode, A., Bonnet, S., Boström, K. H., Böttjer, D., Capone, D. G., Carpenter, E. J., Chen, Y. L., Church, M. J., 
Dore, J. E., Falcón, L. I., Fernández, A., Foster, R. A., Furuya, K., Gómez, F., Gundersen, K., Hynes, A. M., Karl, D. M., Kitajima, S., Langlois, R. J., LaRoche, J., Letelier, R. M., Marañón, E., McGillicuddy Jr., D. J., Moisander, P. H., Moore, C. M., Mouriño-Carballido, B., Mulholland, M. R., Needoba, J. A., Orcutt, K. M., Poulton, A. J., Rahav, E., Raimbault, P., Rees, A. P., Riemann, L., Shiozaki, T., Subramaniam, A., Tyrrell, T., Turk-Kubo, K. A., Varela, M., Villareal, T. A., Webb, E. A., White, A. E., Wu, J., and Zehr, J. P.: Database of diazotrophs in global ocean: abundance, biomass and nitrogen fixation rates, Earth Syst. Sci. Data, 4, 47-73, https://doi.org/10.5194/essd-447-2012, 2012.

Martiny, A. C., Pham, C. T. A., Primeau, F. W., Vrugt, J. A., Moore, J. K., Levin, S. A., and Lomas, M. W.: Strong latitudinal patterns in the elemental ratios of marine plankton and organic matter, Nature Geosci., 6, 279-283, https://doi.org/10.1038/ngeo1757, 2013.

Martínez, L., Silver, M. W., King, J. M., and Alldredge, A. L.: Nitrogen Fixation by Floating Diatom Mats: A Source of New Nitrogen to Oligotrophic Ocean Waters, Science, 221, 152-154, https://doi.org/10.1126/science.221.4606.152, 1983.

Mauriac, R., Moutin, T., and Baklouti, M.: Accumulation of DOC in Low Phosphate Low Chlorophyll (LPLC) area: is it related to higher production under high N:P ratio?, Biogeosciences, 8 , 933-950, https://doi.org/10.5194/bg-8-933-2011, 2011.

Meyers, G.: On the Annual Rossby Wave in the Tropical North Pacific Ocean, J. Phys. Oceanogr., 9, 663-674, https://doi.org/10.1175/15200485(1979)009<0663:OTARWI>2.0.CO;2, 1979.

Mills, M. M., Ridame, C., Davey, M., La Roche, J., and Geider, R. J.: Iron and phosphorus co-limit nitrogen fixation in the eastern tropical North Atlantic, Nature, 429, 292-294, 2004.

Moisander, P. H., Zhang, R., Boyle, E. A., Hewson, I., Montoya, J. P., and Zehr, J. P.: Analogous nutrient limitations in unicellular diazotrophs and Prochlorococcus in the South Pacific Ocean, The ISME Journal, 6, 733-744, 2012.

Monteiro, F. M., Dutkiewicz, S., and Follows, M. J.: Biogeographical controls on the marine nitrogen fixers: controls on marine nitrogen fixers, Global Biogeochem. Cy., 25, https://doi.org/10.1029/2010GB003902, 2011.

Moore, J. K., Doney, S. C., Glover, D. M., and Fung, I. Y.: Iron cycling and nutrient-limitation patterns in surface waters of the World Ocean, Deep Sea Res. Pt. II, 49, 463-507, https://doi.org/10.1016/S0967-0645(01)00109-6, 2002.

Moore, J. K., Doney, S. C., and Lindsay, K.: Upper ocean ecosystem dynamics and iron cycling in a global three-dimensional model: global ecosystem-biogeochemical model, Global Biogeochem. Cy., 18, https://doi.org/10.1029/2004GB002220, 2004.

Moutin, T., Van Den Broeck, N., Beker, B., Dupouy, C., Rimmelin, P., and Le Bouteiller, A.: Phosphate availability controls Trichodesmium spp. biomass in the SW Pacific Ocean, Mar. Ecol. Prog. Ser., 297, 15-21, 2005.

Moutin, T., Karl, D. M., Duhamel, S., Rimmelin, P., Raimbault, P., Van Mooy, B. A. S., and Claustre, H.: Phosphate availability and the ultimate control of new nitrogen input by nitrogen fixation in the tropical Pacific Ocean, Biogeosciences, 5, 95-109, https://doi.org/10.5194/bg-5-95-2008, 2008.

Moutin, T., Doglioli, A. M., de Verneil, A., and Bonnet, S.: Preface: The Oligotrophy to the UlTra-oligotrophy PACific Ex- periment (OUTPACE cruise, 18 February to 3 April 2015), Biogeosciences, 14, 3207-3220, https://doi.org/10.5194/bg-143207-2017, 2017.

Moutin, T., Wagener, T., Caffin, M., Fumenia, A., Gimenez, A., Baklouti, M., Bouruet-Aubertot, P., Pujo-Pay, M., Leblanc, K., Lefevre, D., Helias Nunige, S., Leblond, N., Grosso, O., and de Verneil, A.: Nutrient availability and the ultimate control of the biological carbon pump in the western tropical South Pacific Ocean, Biogeosciences, 15, 2961-2989, https://doi.org/10.5194/bg-15-2961-2018, 2018.

Mulholland, M., Bronk, D., and Capone, D.: Dinitrogen fixation and release of ammonium and dissolved organic nitrogen by Trichodesmium IMS101, Aquat. Microbial. Ecol., 37, 85-94, https://doi.org/10.3354/ame037085, 2004.

Mulholland, M. R. and Bernhardt, P. W.: The effect of growth rate, phosphorus concentration, and temperature on $\mathrm{N}_{2}$ fixation, carbon fixation, and nitrogen release in continuous cultures of Trichodesmium IMS101, Limnol. Oceanogr., 50, 839-849, 2005.

Mulholland, M. R., Bernhardt, P. W., Heil, C. A., Bronk, D. A., and O'Neil, J. M.: Nitrogen fixation and release of fixed nitrogen by Trichodesmium spp. in the Gulf of Mexico, Limnol. Oceanogr., 51, 1762-1776, 2006.

Olsen, A., Key, R. M., van Heuven, S., Lauvset, S. K., Velo, A., Lin, X., Schirnick, C., Kozyr, A., Tanhua, T., Hoppema, M., Jutterström, S., Steinfeldt, R., Jeansson, E., Ishii, M., Pérez, F. F., and Suzuki, T.: The Global Ocean Data Analysis Project version 2 (GLODAPv2) - an internally consistent data product for the world ocean, Earth Syst. Sci. Data, 8, 297-323, https://doi.org/10.5194/essd-8-297-2016, 2016.

Paerl, H. W., Crocker, K. M., and Prufert, L. E.: Limitation of $\mathrm{N}_{2}$ fixation in coastal marine waters: Relative importance of molybdenum, iron, phosphorus, and organic matter availability1, Limnol. Oceanogr., 32, 525-536, https://doi.org/10.4319/lo.1987.32.3.0525, 1987.

Perry, M. J.: Alkaline phosphatase activity in subtropical Central North Pacific waters using a sensitive fluorometric method, Mar. Biol., 15, 113-119, https://doi.org/10.1007/BF00353639, 1972.

Perry, M. J.: Phosphate utilization by an oceanic diatom in phosphorus-limited chemostat culture and in the oligotrophic waters of the central North Pacific1, Limnol. Oceanogr., 21, 88107, https://doi.org/10.4319/lo.1976.21.1.0088, 1976.

Polovina, J. J., Howell, E. A., and Abecassis, M.: Ocean's least productive waters are expanding, Geophys. Res. Lett., 35, L03618, https://doi.org/10.1029/2007GL031745, 2008.

Rabouille, S., Staal, M., Stal, L. J., and Soetaert, K.: Modeling the Dynamic Regulation of Nitrogen Fixation in the Cyanobacterium Trichodesmium sp., Appl. Environ. Microbiol., 72, 3217-3227, https://doi.org/10.1128/AEM.72.5.3217-3227.2006, 2006.

Radenac, M.-H. and Rodier, M.: Nitrate and chlorophyll distributions in relation to thermohaline and current structures in the western tropical Pacific during 1985-1989, Deep Sea Res. Pt. II, 43, 725-752, https://doi.org/10.1016/0967-0645(96)00025-2, 1996.

Rueter, J. G., Ohki, K., and Fujita, Y.: The effect of iron nutrition on photosynthesis and nitrogen fixation in cultures of Trichodesmium (Cyanophyceae), J. Phycol., 26, 30-35, https://doi.org/10.1111/j.0022-3646.1990.00030.x, 1990.

Sañudo-Wilhelmy, S. A., Kustka, A. B., Gobler, C. J., Hutchins, D. A., Yang, M., Lwiza, K., Burns, J., Capone, D. G., Raven, 
J. A., and Carpenter, E. J.: Phosphorus limitation of nitrogen fixation by Trichodesmium in the central Atlantic Ocean, Nature, 411, 66-69, https://doi.org/10.1038/35075041, 2001.

Shamarock, W., Kemp, J. B., Dudhia, J., Gill, D., Barker, D., Duda, M., and Powers, J.: A Description of the Advanced Research WRF Version 3: NCAR Technical Note TN-475+ STR, Tech. rep., National Center for Atmospheric Research Boulder, Colorado, USA, 2008.

Stenegren, M., Caputo, A., Berg, C., Bonnet, S., and Foster, R. A.: Distribution and drivers of symbiotic and free-living diazotrophic cyanobacteria in the western tropical South Pacific, Biogeosciences, 15, 1559-1578, https://doi.org/10.5194/bg-151559-2018, 2018.

Van Den Broeck, N., Moutin, T., Rodier, M., and Le Bouteiller, A.: Seasonal variations of phosphate availability in the SW Pacific Ocean near New Caledonia, Mar. Ecol. Prog. Ser., 268, 1-12, 2004.

Van Wambeke, F., Gimenez, A., Duhamel, S., Dupouy, C., Lefevre, D., Pujo-Pay, M., and Moutin, T.: Dynamics and controls of heterotrophic prokaryotic production in the western tropical South Pacific Ocean: links with diazotrophic and photosynthetic activity, Biogeosciences, 15, 2669-2689, https://doi.org/10.5194/bg15-2669-2018, 2018.

Vidal, M., Duarte, C., Agustí, S., Gasol, J., and Vaqué, D.: Alkaline phosphatase activities in the central Atlantic Ocean indicate large areas with phosphorus deficiency, Mar. Ecol. Prog. Ser., 262, 4353, https://doi.org/10.3354/meps262043, 2003.

Vrede, K., Heldal, M., Norland, S., and Bratbak, G.: Elemental Composition (C, N, P) and Cell Volume of Exponentially Growing and Nutrient-Limited Bacterioplankton, Appl. Environ. Microbiol., 68, 2965-2971, https://doi.org/10.1128/AEM.68.6.2965-2971.2002, 2002.
Wu, J., Sunda, W., Boyle, E. A., and Karl, D. M.: Phosphate depletion in the western North Atlantic Ocean, Science, 289, 759-762, 2000.

Zamora, L. M., Landolfi, A., Oschlies, A., Hansell, D. A., Dietze, H., and Dentener, F.: Atmospheric deposition of nutrients and excess $\mathrm{N}$ formation in the North Atlantic, Biogeosciences, 7, 777793, https://doi.org/10.5194/bg-7-777-2010, 2010.

Zehr, J. P. and Kudela, R. M.: Nitrogen Cycle of the Open Ocean: From Genes to Ecosystems, Annu. Rev. Mar. Sci., 3, 197-225, https://doi.org/10.1146/annurev-marine-120709-142819, 2011.

Zehr, J. P. and McReynolds, L. A.: Use of degenerate oligonucleotides for amplification of the nifH gene from the marine cyanobacterium Trichodesmium thiebautii, Appl. Environ. Microbiol., 55, 2522-2526, 1989.

Zehr, J. P. and Turner, P. J.: Nitrogen fixation: Nitrogenase genes and gene expression, in: Methods in Microbiology, vol. 30 of Marine Microbiology, 271-286, Academic Press, https://doi.org/10.1016/S0580-9517(01)30049-1, 2001.

Zhang, R.-H., Busalacchi, A. J., and Xue, Y.: Decadal change in the relationship between the oceanic entrainment temperature and thermocline depth in the far western tropical Pacific, Geophys. Res. Lett., 34, L23612, https://doi.org/10.1029/2007GL032119, 2007.

Zimmerman, A. E., Allison, S. D., and Martiny, A. C.: Phylogenetic constraints on elemental stoichiometry and resource allocation in heterotrophic marine bacteria, Environ. Microbiol., 16, 13981410, https://doi.org/10.1111/1462-2920.12329, 2014.

Zweng, M. M., Reagan, J. R., Antonov, J. I., Locarnini, R. A., Mishonov, A. V., Boyer, T. P., Garcia, H. E., Baranova, O. K., Johnson, D. R., Seidov, D., and Biddle, M. M.: World ocean atlas 2013. Volume 2, Salinity, Tech. rep., NOAA Atlas NESDIS 74, https://doi.org/10.7289/V5251G4D, 2013. 